\title{
DO RURAL BANKS MATTER? \\ EVIDENCE FROM THE INDIAN SOCIAL BANKING EXPERIMENT
}

\author{
Robin Burgess \\ London School of Economics and Political Science
}

and

Rohini Pande

Yale University

Contents:

1. Introduction

2. Data and Program Description

3. Identification Strategy

4. Effects on Rural Development

5. Discussion

References

Data Appendix

Tables $1-11$

Figures 1 - 9

Discussion Paper

No. DEDPS/40

August 2003
The Suntory Centre

Suntory and Toyota International Centres for

Economics and Related Disciplines

London School of Economics and Political Science

Houghton Street

London WC2A 2AE

Tel.: 020-7955 6674

We thank Esther Duflo for very helpful and detailed comments. We have benefited from comments and suggestions from Josh Angrist, Abhijit Banerjee, Tim Besley, Richard Blundell, Bronwen Burgess, Anne Case, Ken Chay, Dom Leggett, Jonathan Murdoch, Atif Mian, Andrew Newman, Debraj Ray, Mark Rosenzweig, Ken Sokoloff, Duncan Thomas, Robert Townsend, and seminar participants at the Bureau for Research in Economic Analysis of Development (BREAD) 2002 Meeting, Caltech, Cornell, Harvard, IMF, LSE, Michigan, MIT, NYU, Princeton, Southampton, Stanford, Stockholm, UBC, UCLA, UCSD, World Bank and Yale. Juan de Laiglesia, Mattia Romani, Gaurav Shah, Heideeflower Stoller and Grace Wong provided exceptional research assistance. 


\begin{abstract}
Lack of access to finance is often cited as a key reason why poor people remain poor. This paper uses data on the Indian rural branch expansion program to provide empirial evidence on this issue. Between 1977 and 1990, the Indian Central Bank mandated that a commercial bank can open a branch in a location with one or more bank branches only if it opens four in locations with no bank branches. We show that between 1977 and 1990 this rule caused banks to open relatively more rural branches in Indian states with lower initial financial development. The reverse is true outside this period. We exploit this fact to identify the impact of opening a rural bank on poverty and output. Our estimates suggest that the Indian rural branch expansion program significantly lowered rural poverty, and increased non-agricultural output.
\end{abstract}

Keywords: Finance and development; rural banking; bank licensing; credit constraints; structural change; diversification; redistribution; poverty, growth.

JEL Nos.: E5, G2, H1, H4, I3, N2, O0, O1, O2, O4.

(C) The authors. All rights reserved. Short sections of text, not to exceed two paragraphs, may be quoted without explicit permission provided that full credit, including $\odot$ notice, is given to the source.

Contact address:

Dr Robin Burgess, STICERD, London School of Economics and Political Science, Houghton Street, London WC2A 2AE, UK. Email: r.burgess@Ise.ac.uk 


\section{Introduction}

A key objective in development economics is to work out ways to lift people out of poverty. Access to finance has been seen as a critical factor in enabling people to transform their production and employment activities and to exit poverty (Banerjee and Newman 1993; Aghion and Bolton 1997; Banerjee, 2001). Countries with better developed financial systems, it is argued, should be better able to exploit growth opportunities (Schumpeter, 1934; Gerschenkron 1962; Greenwood and Jovanovic, 1990; Bencivenga and Smith, 1991). Financial development may also enhance financial stability with positive implications for economic performance (Bernanke and Gertler, 1990). While these arguments have often provided the theoretical justification for widespread government intervention in the banking sector, evidence on the success of such interventions in reducing poverty remains limited. ${ }^{1}$ In this paper we use data on the Indian rural bank branch expansion program - the largest ever attempted in a developing country - to provide such evidence.

The Indian branch expansion program was representative of a whole host of stateled rural finance programs that spread across the developing world in the post-colonial period. This trend was not restricted to low income countries - in the United States, for example, the Community Reinvestment Act of 1977 requires a bank to meet the credit needs of its entire community, including low income neighborhoods (Zinman 2002). In most cases such financial interventions went hand in hand with government oversight of the banking sector, often aided by government ownership of banks. ${ }^{2}$

However, it is now widely believed that state control of the banking sector implied that political, not economic, considerations determined the flow of credit across sectors and individuals. Political imperatives also implied that widespread loan default on the part of borrowers was permitted, and made the banking sector more susceptible to elite capture (La Porta, Lopez-De-Silanes and Shleifer, 2003; Sapienza, 2003). Some go as far as to claim that elite capture, combined with the imposition of interest rate ceilings in the formal sector, led to financial dualism wherein formal subsidized funds are concentrated in the hands of the powerful few and terms in the informal markets (on which the poor depend) worsened (see Adams et al 1984; Braverman and Guasch 1986; Hoff and Stiglitz, 1998). In sum, it is believed that formal subsidized credit was ineffective in reaching the poor, and may even have undermined rural development and increased rural poverty.

However, the evidence in support of such claims remains thin. By virtue of their vintage social banking episodes, though numerous and large in scale, have largely escaped serious evaluation. And this is despite the fact that, even today, state provision remains the dominant source for formal finance in the rural areas of developing

\footnotetext{
${ }^{1}$ Cross country data shows that banking expansion and economic growth are positively correlated (King and Levine, 1993; Levine and Zervos, 1998; Rajan and Zingales, 1998). However, the fact that countries (or regions) with greater growth potential attract more banks renders a causal interpretation problematic. In addition, the absence of comparable cross-country poverty data across time makes working out the distributional impact of banking expansion problematic.

${ }^{2}$ La Porta, Lopez-De-Silanes and Shleifer (2002) report that, in the average country, 42 percent of the equity of the ten largest banks remained government owned in 1995.
} 
countries (Besley 1995). This paper seeks to address this lacuna in the literature. India is an appropriate place for such an evaluation, both because of the size and scope of the social banking experiment and also because it is home to close to a third of the world's poor, the bulk of whom are located in rural areas (Deaton and Dreze, 2002).

Between bank nationalization in 1969 and the onset of financial liberalization in 1990 bank branches were opened in over 30,000 rural locations which had no prior presence of commercial banks (henceforth, unbanked locations). ${ }^{3}$ Alongside, the share of bank credit and savings which was accounted for by rural branches rose from 1.5 and 3 percent respectively to 15 percent each. The branch expansion program was an integral part of India's social banking experiment which sought to improve the access of the rural poor to cheap formal credit. The preamble to the Bank Company Acquisition Act of 1969 - the piece of legislation which empowered the state to nationalize commercial banks - makes the intentions of the Indian government plain.

"The Banking system touches the lives of millions and has to be inspired by a larger social purpose and has to subserve national priorities and objectives such as rapid growth of agriculture, small industries and exports, raising of employment levels, encouragement of new entrepreneurs and development of backward areas. For this purpose it is necessary for the government to take direct responsibility for the extension and diversification of banking services and for the working of a substantial part of the banking system".

Key to the rural branch expansion endeavor was the imposition of the 1:4 license rule in 1977. This rule stated that a bank could open a branch in a location with one or more branches (now on, a banked location) only if it opened four in unbanked locations. This rule was abandoned in 1990. States with lower initial financial development (as measured by the number of bank branches per capita in 1961) had a higher incidence of unbanked locations. We use a panel data-set for the sixteen major Indian states (1961-2000), and show that, between 1977 and 1990, the 1:4 license rule caused financially less developed states to attract more rural branches than their more financially developed counterparts. The reverse was true outside this period.

We show that an identical temporal and geographic pattern exists for rural poverty - rural poverty reductions were more rapid in states with lower financial development between 1977 and 1990. The opposite was true outside this period. In contrast, political and policy variables which may have reduced poverty in India over this period did not show trend breaks in their relationship with initial financial development in 1977 or 1990. This allows us to use the trend breaks in 1977 and 1990 in the relationship between a state's initial financial development and rural branch expansion as instruments for the number of rural locations banked in a state. Our instrumental variable estimates suggest that a one percent increase in the number of rural banked locations reduced rural poverty by 0.36 percent and increased total output by 0.55

\footnotetext{
${ }^{3}$ Locations here refer to villages, towns and cities as defined by the Indian census.
} 
percent. The output effects are solely accounted for by increases in non-primary sector output - a finding which suggests that increased financial intermediation in rural India aided output and employment diversification out of agriculture.

The rapid increase in the Indian rural branch network and rural credit and savings share after bank nationalization in 1969, and the subsequent slowdown post 1990, has been widely documented (Nair 2000). However, evidence on the impact of the social banking program on poverty remains limited. Our findings on output line up with Binswanger, Khandker and Rozensweig (1993) and Binswanger and Khandker (1995). These papers use Indian district-level data, and find that rural branch expansion increased non-agricultural but not agricultural growth. ${ }^{4}$ Our results are also consistent with the simulations by Townsend and Ueda (2001) based on Thai data which show that increased participation in the formal financial sector enhances growth. By exploiting the policy induced reversal in the relationship between initial branch placement we are able to control for endogenous bank branch placement and to identify the impact of rural branch expansion on poverty. Our identification strategy is related to a number of recent program evaluation studies which exploit policy-induced trend breaks in the variables of interest for identification purposes important related examples include Duflo (2001) and Almond, Chay and Greenstone (2002).

The paper is organized as follows. Section 2 describes the data we use, and the program we study. Section 3 contains our identification strategy, and Section 4 the empirical analysis. Section 5 discusses the policy implications of our findings.

\section{Data and Program Description}

\section{$2.1 \quad$ Data}

We use a panel data-set for the sixteen major Indian states over the period 1961-2000. We start in 1961 as it is the year of the census which preceded bank nationalization. Also, our poverty and output series begin around this year. Table 1 gives the means and standard deviations for our main variables and the Data Appendix information on variable definitions and data sources. ${ }^{5}$

We use a branch level data-set which records, for every bank branch opened since 1805, the date it was opened, whether it was situated in a rural location and the number of branches already existing in that location to construct three measures of financial development (Reserve Bank of India, 2000). ${ }^{6}$ The number of bank branches per 100,000 persons in a state in 1961 is our measure of initial financial development.

\footnotetext{
${ }^{4}$ Eastwood and Kohli (1999) use firm level data and find that the branch expansion program and directed lending program enhanced small scale industrial activity in India. Our findings are also in line with Dehejia and Lleras-Muney (2002) who find that financial development was associated with manufacturing growth in US states between 1900 and 1940.

${ }^{5}$ The sixteen states in our sample cover over $95 \%$ of the Indian population. For some variables the data span fewer years; details are in the Data Appendix.

${ }^{6}$ We always use the census definition of a rural location - that is, a location with a population of less than 10,000 persons. This is the same definition used to distinguish rural from urban poverty.
} 
If a branch is the first to be opened in a rural location we classify it as having opened in a rural unbanked location. In our sample states between 1961 and 2000 the number of rural locations so banked increased from 116 to 30,428. The total number of branches opened in rural unbanked locations per 100,000 persons is our 'social banking' measure. A branch opening in a census location with at least one bank is classified as opening in a banked location. Our third measure of financial development is the number of branches opened in already banked locations per 100,000 persons. Figure 1 charts the evolution of (cumulative) branch openings in banked, unbanked and rural unbanked locations.

Every bank branch in our sample is a distinct physical entity which undertakes both deposit-taking and lending activities. ${ }^{7}$ Deposit taking is relatively straightforward, with the interest rate and other terms and conditions laid down by the Indian central bank. In the area of lending, bank branch officials enjoy discretion in choosing borrowers, subject to satisfying directed lending targets for the so-called 'priority' sectors of agriculture, entrepreneurs and small scale industry. The Indian central bank mandates that every bank branch satisfy a credit-deposit ratio of 60 percent within its geographical area of operation - this is to ensure that lending activities are not concentrated in urban locales.

In 2000, the Indian rural banking sector accounted for the rupee equivalent of 26,768 million dollars as deposits and 10,834 million dollars as loans outstanding. In terms of population reached, the rural sector accounted for 125 million savings accounts and 25 million borrowing accounts. ${ }^{8}$ Figure 2 shows the dramatic expansion in rural savings and credit over our sample period; the figure plots the state-wise shares of total bank credit and savings accounted for by rural banks. Finally, in terms of lending portfolio the average rural bank lent 38.6 percent to agriculture, 27.5 percent to industry, 13.9 percent to trade and 9 percent as personal loans (Reserve Bank of India, 2000).

In Table 2, we use Indian household survey data to decompose rural household debt by source for ten year intervals between 1951 and 1991. In 1951, four years after independence, the informal credit sector accounted for the bulk of rural lending, with moneylenders contributing close to 70 percent of the total. In contrast, less than one percent of rural household debt came from commercial banks. These banks were confined to urban areas and geared towards the financing of trade and commerce activities (Reserve Bank of India, 1954). ${ }^{9}$ By 1971 lending by commercial banks contributed only 3 percent to rural household debt. However, by 1991 this figure

\footnotetext{
${ }^{7}$ The average bank branch is staffed by one officer, two clerks, one of whom also acts as the cashier, and one security guard.

${ }^{8}$ If we assume every savings account is held by a different person and the rural population consisted of 700 million persons in 2000 , then roughly one in every five or six rural persons had a savings account by 2000 .

${ }^{9}$ These findings were published the 1951 All-India Credit Survey Report (Reserve Bank of India, 1954). It concluded that financial backwardness was a root cause of rural poverty, and that commercial banks needed to be harnessed to enhance formal credit in rural areas - both to enable poor, rural households to adopt new technologies and production processes, and to displace 'evil' moneylenders who exploited their monopoly power to charge high rates of interest. These conclusions guided Indian rural banking policy for the next four decades.
} 
had risen ten fold to 29 percent. Over the same time period the moneylender share of rural household debt more than halved from 35 to 15.7 percent. Thus over this period, arguably due to the large scale expansion of commercial banks into rural India, commercial banks transited from being the smallest to the largest lender in rural areas. Our focus is on identifying the economic implications of this change in rural India.

India is unique amongst developing countries in having carried out household expenditure surveys on a regular basis since the 1950s. This allows us to construct a consistent and comparable series of rural and urban poverty measures across our period. ${ }^{10}$ We use the head count ratio which measures the proportion of the population below the Indian poverty line. Poverty incidence in India is high - over the 1961-2000 period 48 percent of the rural and 40 percent of the urban population are classified as poor. Figure 3 shows the evolution of poverty across Indian states between 1961 and 1990. Up to the early 1970s there are sharp year-to-year fluctuations followed by a downward trend in both the rural and urban series between 1973 and 1990. Immediately after 1990, as India entered a period of economic liberalization, the pattern becomes less clear with considerable debate over the net direction (Deaton 2001). The most recent figures suggests that the post 1990 trend is overall downward. What is even more striking, however, are the differences in poverty trajectories across states. A key objective of this paper is to examine whether the pattern of branch expansion into rural unbanked areas altered these rural poverty trajectories. Over this period real male agricultural wages, an important inverse correlate of rural poverty, doubled. Given the controversy surrounding the more recent poverty figures using agricultural wages as an alternative dependent variable provides a useful robustness check.

Separate output estimates for the rural and urban sectors of an Indian state are unavailable. For this reason, we focus on the sector-wise evolution of state output. The primary sector which includes agriculture, forestry, fisheries and mining is mainly rural. The secondary sector consists of construction, registered and unregistered manufacturing, and electricity, water and gas output. Of these, construction and registered manufacturing are mainly located in the urban sector, while unregistered manufacturing (which consists of small businesses which employ less than ten persons with power, or twenty without) and electricity, water and gas output have a substantial rural presence. The tertiary sector consists of various service sectors such as trade and transportation which occur in both rural and urban areas. In 1961 the primary sector contributed the most to total state output; however, since the mid 1970s the growth rates in the non-primary sector exceeded those in the primary sector (see Figure 4). We examine the links, if any, between rural branch expansion and sector-wise increases in economic activity. Evidence both from the economic history and economic development literatures suggests the process of structural change, where the secondary and tertiary sectors become the main contributors to total output, is typically associated with poverty reduction (see Chenery, Robinson

\footnotetext{
${ }^{10}$ We are grateful to Gaurav Datt and Martin Ravallion for providing us these state-level poverty figures (see Ozler, Datt and Ravallion (1996)). Gaurav Datt was kind enough to provide us with comparable updates which allowed us to extend the series from 1994-2000.
} 
and Syrquin, 1986; Dehejia and Lleras-Muney, 2002; Burgess and Venables, 2003). We also examine whether the fraction of non-agricultural laborers in the rural labor force is affected.

\subsection{The Program}

In 1969 the fourteen largest Indian commercial banks were nationalized, at which point they came under the direct control of the Indian central bank and were formally incorporated into the planning architecture of the country (Balachandran, 1998). Bank nationalization was intended to allow the state to target financial backwardness as a means of promoting social objectives. A central aim was to reduce and equalize the average population per bank branch across Indian states.

To achieve this the Indian central bank adopted an area approach whereby unbanked locations - census locations with no prior presence of commercial banks were targeted (Desai 1987). At any point in time, the central bank sought to fill unbanked locations with populations exceeding a specific number. Unbanked locations in states whose population per bank branch exceeded the national average had priority. Over time, as unbanked locations were filled, the population target was lowered. The priority status assigned to financially less developed states, combined with a common definition for unbanked locations across Indian states, meant that more unbanked locations were targeted in financially backward states.

In every Indian district a commercial bank was designated as the Lead Bank and made responsible for identifying unbanked locations (based on the criteria set by the central bank). Every three years new (district-wise) lists of unbanked locations were drawn up by the central bank (in consultation with Lead Banks and state development authorities) and made available to commercial banks working in a district. The Lead Bank was responsible for coordinating branch expansion into these locations with other commercial banks working in the district. ${ }^{11}$

The Indian central bank, however, still needed to coerce commercial banks to expand into unbanked, rural locations. In particular, in states where unbanked locations were remote and/or unprofitable. Under the Banking Regulation Act of 1949 commercial banks have to obtain a license from the central bank in order to open a new branch. On January 1, 1977 the Indian central bank announced that to qualify to open a branch in an already banked location a commercial bank must open four in unbanked locations. ${ }^{12}$ In 1990 the licensing procedure was frozen, and in 1991 formally repealed. At this point it was deemed that future branch expansion should depend on "need, business potential and financial viability of location" (Government of India, 1991).

Branch level data shows that the 1:4 rule was binding - the annual ratio of bank branches opened in unbanked locations to total branches opened stands at, or around,

\footnotetext{
${ }^{11}$ The district is the administrative unit below a state. An alternative would be undertake the analysis at the district level. However, annual poverty and output estimates are only available at the state level.

${ }^{12} \mathrm{Up}$ to this point banks had enjoyed some latitude as regards branch placement as the central bank emphasized the banking of towns and the need to satisfy pent up urban demand.
} 
0.8 for every year between 1977 and 1990, and falls to zero thereafter. This effect is also visible in Figure 1 which shows that from about 1975 onwards, increases in the number of locations banked are due to increases in the number of rural locations banked. Between 1977 and 1990 branch expansion into rural unbanked locations accelerated while that of already banked locations fell. After 1990 branch expansion in unbanked locations came to a halt, while that in already banked locations increased. To date, a bank cannot close a rural branch if it is the only branch servicing the location. The 1990 rural branch network is therefore, in effect, frozen. ${ }^{13}$

The typical commercial bank in India operates in districts in both financially developed and backward states (either as a Lead Bank or collaborator). The central bank prioritized branch expansion in financially backward states, and this was reflected in the unbanked location lists. Therefore, compliance with the 1:4 rule implied that banks opened more branches in unbanked locations in financially backward states. Figure 5 shows the equalization and reduction in population per bank branch across Indian states over this period. Between 1961 and 2000 the average population per bank branch fell tenfold from 139,790 to 14,681 . There is some, albeit limited, evidence of convergence in population per bank branch across Indian states prior to nationalization. Convergence, however, is much stronger between 1970 and 1990, with the post-1976 convergence driven by differential rates of rural branch expansion across Indian states. By 1990, all states were at or below the national target of 17,000 persons per bank branch. Interestingly, after the removal of placement restrictions in 1990 and an increase in branch building in already banked locations there is some evidence that population per bank branch began to increase and diverge across Indian states with more backward states seeing larger increases (see inset panel, Figure $5)$.

This period also saw the central bank affect the credit policies of commercial banks. Since 1968, the central bank has mandated that a certain fraction of every bank's lending had to be to individuals or firms who are in the 'priority' sector. This sector includes agriculture, entrepreneurs and small scale industries. ${ }^{14}$ These loans were intended to encourage new productive activities, and were also disbursed via rural bank branches. However, unlike rural branch expansion, the incidence of these credit policies does not vary with a state's initial financial development.

\section{Identification Strategy}

In this section we demonstrate that the bulk of rural branch expansion in India was policy-driven and significantly increased the flows of bank credit and savings to rural areas. The first fact allows for a credible evaluation of the branch expansion program, and the second implies we can interpret our results as informative of the economic

\footnotetext{
${ }^{13}$ Additional credit needs of the rural population post 1990 are supposed to be met through other means, principally microfinance (Ramachandran and Swaminathan, 2001).

${ }^{14}$ These targets were ratcheted up over time - they started at 33 percent of total bank lending and have stood at 40 percent since 1985 .
} 
impact of state-led financial intermediation. ${ }^{15}$

The 1:4 license rule sought to coerce commercial banks to open more branches in rural unbanked locations in less financially developed states. The underlying assumption was that financially developed states offered more profitable locations for banks and therefore, in the absence of such a rule, would attract more branches. This suggests that if the rule had any bite its imposition in 1977 and subsequent removal in 1990 should have altered the relationship between initial financial development of a state and subsequent rural branch expansion. To examine this possibility we run a fixed effects regression of the form:

$$
B_{i t}^{R}=\alpha_{i}+\beta_{t}+\sum_{t=1961}^{2000}\left(B_{i 61} \times D_{k}\right) \gamma_{k}+\sum_{t=1961}^{2000}\left(X_{i 61} \times D_{k}\right) \delta_{k}+\epsilon_{i t}
$$

$\alpha_{i}$ and $\beta_{t}$ are state and year effects respectively. $B_{i t}^{R}$, the number of branches opened in rural unbanked locations per capita, is our social banking measure and $B_{i 61}$, the number of bank branches per capita in state $i$ in 1961, our measure of initial financial development. ${ }^{16} D_{k}$ is a dummy which equals one where $k=t$. The coefficient set $\gamma_{k}$ captures the year-wise effect of initial financial development on rural branch expansion. As other initial conditions in a state may also have a time-varying effect on branch expansion we include a vector of control variables $\left(X_{i 61}\right)$ as additional covariates. This vector includes log real state income per capita, population density and the number of rural locations per capita, all measured in 1961. These controls also enter the regression interacted with year dummies.

Figure 6 graphs the $\gamma_{k}$ coefficients for two specifications. The dots on the solid line are the coefficients from a specification without the $X_{i 61}$ controls, and the dots on the broken line are from a specification with the $X_{i 61}$ controls. In both cases 1961 is the control year, and the 1961 dummy is omitted. ${ }^{17} \gamma_{k}$ summarizes the effect of between-state variation in initial financial development on the cumulative number of branches opened in rural unbanked locations as of year $t$. As our dependent variable is a cumulative variable, a comparison of the coefficients for any two adjacent years $\left(\gamma_{k}\right.$ and $\left.\gamma_{k+1}\right)$ is informative of the relationship between initial financial development and the growth in rural branch openings.

Over this period the number of rural banked locations trend upwards in every state. However, two clear reversals in the relationship between a state's initial financial development and the number of rural banked locations stand out in Figure 6 - one in 1977 and one in 1990. Between 1961 and 1977 the $\gamma_{k}$ coefficients increase with time - that is, financially more developed states witness higher growth of rural banked locations. As banks enjoyed considerable leeway regarding where to locate

\footnotetext{
${ }^{15}$ Our focus on the economic impact of bank branches sidesteps many of the endogeneity problems associated with a direct study of the impact of credit flows. In a similar vein Jayarathne and Strahan (1996) use information on when a U.S. state relaxed branching restrictions to examine how financial markets affect economic growth

${ }^{16}$ Both variables are normalized by 1961 population. The results are also robust to, instead, normalizing the banking variables by land area (as in Binswanger, Khandker and Rosenzwieg 1993).

${ }^{17}$ We chose 1961 as it is the census year preceding bank nationalization. Our results are robust to choosing any alternative year as the control year.
} 
this suggests that financially more developed states offered banks greater profit opportunities. This relationship is reversed in 1977 precisely when the 1:4 license rule was imposed. Moreover, the reversal is not temporary. Between 1977 and 1990 the $\gamma_{k}$ coefficients decrease with time - that is, financially less developed states witnessed higher growth of rural banked locations. After 1990 rural branch expansion into rural unbanked locations ended, and is reflected in the lack of over time variation in the size of the $\gamma_{k}$ coefficients. Overall, the precise correspondence in the timing of these trend reversals and license regime shifts provides strong prima facie evidence that the pattern of rural branch expansion across Indian states was policy driven.

We include the vector of economic controls, $X_{i 61}$, as additional controls to check that convergence in economic activity (as proxied for by income, population density or number of rural locations) across Indian states is not driving the observed relationship between rural branch expansion and initial financial development. The broken line graph in Figure 6 shows that this is not the case. If we graph out the $\delta_{k}$ coefficients for the interaction between initial state income and year dummies we find the relationship between initial state income and rural branch expansion is throughout positive (i.e. the graph is upward sloping). That is, controlling for initial financial development, banks open more branches in states with higher initial state income. ${ }^{18}$

Further evidence that economic convergence does not underlie the trend reversals in Figure 6 comes from data on branch openings in already banked locations. The 1:4 license rule linked branch expansion in already banked locations to that in unbanked locations. Banks, however, were free to decide branch placement in already banked locations. If the relationship between initial financial development and bank profitability remained unchanged during this period, then the imposition and subsequent removal of the 1:4 license rule should have affected the rate of branch expansion in already banked locations but not its distribution across states. To check this we run regression (1) where the outcome variable is the cumulative number of branches opened in banked locations per capita. Figure 7 graphs out the $\gamma_{k}$ coefficients on the interaction between initial financial development of a state $\left(B_{i 61}\right)$ and year dummies $\left(D_{k}\right)$. This relationship, though affected by license regime shifts in 1977 and 1990, is positive throughout. This mirrors what was happening with branch openings in rural unbanked locations pre-1977 but is in strict contrast to what was happening between 1977 and 1990.

In Figure 8 we examine the relationship between rural bank credit and initial financial development. That is, we report the $\gamma_{k}$ coefficients from regression (1) where the dependent variable is the share of bank credit disbursed by rural branches. ${ }^{19} \mathrm{We}$ observe a pattern that mirrors that for rural unbanked locations (Figure 6). Disbursements via rural banks are higher in more financially developed states until around 1975 when there is a trend reversal. Between 1976 and 1989 we see more backward states experiencing a greater share of credit being disbursed via rural banks. After 1989 the relationship between rural credit share and initial financial development

\footnotetext{
${ }^{18}$ For obvious reasons, this relationship is much more muted between 1977 and 1990 if we exclude the interaction between initial financial development and year dummies from this regression.

${ }^{19}$ Data on credit and savings flows from rural banks is only available from 1969.
} 
reverts to being broadly positive. A similar pattern exists for the rural savings share. The most likely explanation for the negative relationship between credit and saving flows and initial financial development between mid 1970s and 1990 is the higher growth of rural branches in financially backward states. These findings put us on stronger grounds in interpreting the economic effects of rural banks as coming, at least in part, through improved financial intermediation in rural areas.

The key trend reversals in the relationship between rural branch expansion and initial financial intermediation occur in 1977 and 1990, with only very limited variation in this relationship in other years (Figure 6). The variation in Figure 6 can, therefore, be summarized by a linear trend break model:

$$
\begin{aligned}
B_{i t}^{R}= & \alpha_{i}+\beta_{t}+\left(B_{i 61} \times[t-61]\right) \gamma_{1}+\left(B_{i 61} \times[t-76] \times P_{77}\right) \gamma_{2}+ \\
& \left(B_{i 61} \times[t-89] \times P_{90}\right) \gamma_{3}+\left(B_{i 61} \times P_{77}\right) \gamma_{4}+\left(B_{i 61} \times P_{90}\right) \gamma_{5}+\epsilon_{i t} .
\end{aligned}
$$

The first coefficient of interest, $\gamma_{1}$, measures the trend relationship between initial financial development $\left(B_{i 61}\right)$ and rural branch expansion. To check for trend reversals in this relationship we include two further interaction terms - first, an interaction of $B_{i 61}$ with dummy variable which equals one post $1976\left(P_{77}\right)$ and a post 1976 time trend $(t-76)$, and second, an interaction of $B_{i 61}$ with a dummy variable which equals one post $1990\left(P_{90}\right)$ and a post 1989 time trend $(t-89)$. To allow for intercept changes we also include the interactions of $B_{i 61}$ with $P_{77}$ and $P_{90}$ respectively. Finally, we always include the set of additional controls $X_{i 61}$, entered in the regression in the same way as $B_{i 61}$. A standard concern with difference in difference estimation using panel data is serial correlation. Therefore in all regressions we cluster our standard errors by state. This procedure gives us an estimator of the variance covariance matrix which is consistent in the presence of any correlation pattern within states over time (Bertrand, Duflo and Mullainathan, 2002). ${ }^{20}$

Column (1) in Table 3 reports the trend break model results for branch expansion into rural unbanked locations. Both the 1977 and 1990 trend reversals are statistically significant which lines up with the pattern observed in Figure 6. It is useful to interpret the reported coefficients with reference to the states at the 25 th and 75 th percentile of the initial financial development distribution - Madhya Pradesh and Tamil Nadu respectively. The initial financial development of these two states differ by one point. The coefficient $\gamma_{1}$, given in the first row, tells us that between 1961 and 1976, relative to Madhya Pradesh, 0.08 additional rural locations per capita were banked in Tamil Nadu. The second row, which reports $\gamma_{2}$, shows that this positive trend was reversed between 1977 and 1990 with 0.16 fewer rural locations receiving a branch in Tamil Nadu annually relative to Madhya Pradesh. ${ }^{21}$ Finally, the third row, which reports $\gamma_{3}$, tells us that after 1989 no rural branch expansion occurred and hence, Tamil Nadu and Madhya Pradesh were equally likely to receive rural

\footnotetext{
${ }^{20}$ As Bertrand et al (2002) demonstrate for the US rejection rates using this method do increase above 5 percent when the number of states falls below 20. As we only have 16 states in India the significance levels we obtain using this method should be treated as conservative.

${ }^{21}$ This is given by $\gamma_{1}+\gamma_{2}$. F-test 1 shows that $\gamma_{1}+\gamma_{2}$ is significantly different from zero.
} 
branches. ${ }^{22}$ In contrast, and in line with Figure 7, the results for branch expansion into banked locations shown in column (2) do not show any trend reversals.

Columns (3) and (4) consider the relationship between the shares of bank credit and savings disbursed by rural branches and initial financial development. ${ }^{23}$ Prior to 1977 both variables are uncorrelated with initial financial development. However, between 1977 and 1990 both are significantly negatively correlated with initial financial development. Rural credit share exhibits a second trend reversal in 1990 with rural credit and initial financial development unrelated after 1990. Rural savings, however, remain negatively related with initial financial development post 1990. In column (5) we find no evidence of trend reversals in the case of the share of bank lending going to priority sectors. This makes sense as priority sector targets were set at the bank-level, and remained independent of the state-wise distribution of a commercial bank's rural and urban branches. In a similar vein in column (6) we see no trend breaks in the relationship between the share of formal credit disbursed by rural credit cooperatives and initial financial development. ${ }^{24}$ The fact that the trend breaks are only observed for variables which were directly affected by licensing rule increases our confidence that the observed trend reversals are policy-driven.

\section{Effects on Rural Development}

The exposure of an Indian state to the rural branch expansion program was jointly determined by its initial financial development and the license regime shifts in 1977 and 1990. Between 1977 and 1990 initial financial development and rural branch expansion were negatively correlated, with the reverse true outside this time-period. We exploit this fact to provide two types of evidence on the link between rural development and rural branch expansion. In section 4.1 we check whether rural development outcomes also exhibit trend breaks in 1977 and 1990 in their relationship with initial financial development, and in section 4.2 we use these trend breaks as instruments for rural branch expansion.

\subsection{Reduced Form Evidence}

\section{Basic Results}

We start by examining the relationship between initial financial development and poverty outcomes. The bold line in Figure 9 traces out the $\gamma_{k}$ coefficients for a regression (of the form in equation (1)) where rural poverty is the dependent variable, and the dotted line the $\gamma_{k}$ coefficients from a regression where urban poverty is the dependent variable. Each $\gamma_{k}$ summarizes the effect of between state variation in initial financial development on poverty in year $t$. The pattern across years thus tells how poverty rose or fell in relation to the financial development of a state. In

\footnotetext{
${ }^{22} \gamma_{1}+\gamma_{2}+\gamma_{3}$ equals zero. $F$-test 2 shows that $\gamma_{1}+\gamma_{2}+\gamma_{3}$ does not differ significantly from zero.

${ }^{23}$ These data are only available from 1969.

${ }^{24}$ Credit cooperatives were the other main source of formal credit in rural areas across the 19612000 period.
} 
interpreting these coefficients it is useful to remember that over our sample period both rural and urban poverty series trend downwards (Figure 3). Figure 9 shows that between 1970 and 1978 both rural and urban poverty correlate negatively with financial development. That is poverty falls more rapidly in states with higher initial financial development. After this the two series diverge. The urban poverty series flattens out in 1978 with the $\gamma_{k}$ coefficients close to zero until 1990. In contrast, the rural poverty series continues its downward trend until the early 1980s after which rural poverty reductions are more pronounced in less developed states until $1990 .^{25}$ After 1990 both series return to being negatively correlated with financial development as they were pre-1978. The plot for rural poverty in Figure 9 is thus the inverse of that for rural branch expansion in Figure 6. Backward states, in contrast, did not experience more rapid urban poverty reduction between 1977 and 1990. This matches up with the fact that branch expansion into urban locales which tended to be already banked was higher in financially developed states throughout the period (Figure 7).

In Table 4 we summarize these, and other, findings for poverty outcomes using our basic trend break model (see equation (2)). In column (1) we observe that rural poverty reduction is more rapid in financially developed states both before 1977 and after 1990. This trend is, however, reversed between 1977 and 1990. Comparing the states at the 25th (Madhya Pradesh) and 75th percentile (Tamil Nadu) of the initial financial development distribution these coefficients imply that annual reductions in the rural head count ratio were 0.77 percent higher in Tamil Nadu than Madhya Pradesh before 1977. However, between 1977 and 1990 this trend was reversed with Madhya Pradesh experiencing a 1.15 percent more rural poverty reduction per year relative to Tamil Nadu. There is then a second reversal in 1990 when rural branch expansion is discontinued. After this year the more developed state (Tamil Nadu) experiences 1.15 percent more rural poverty reduction per year relative to the more backward state (Madhya Pradesh). These results strongly suggest that more rapid expansion of rural bank branches into more financially backward states during the 1977-1990 period is affecting poverty reduction in these states relative to what was happening in more financially developed states.

Consistent with the fact that we are evaluating a rural program, column (2) shows that initial financial development and urban poverty reductions are unrelated. Rural poverty tends to lie above urban poverty in India (see Figure 3). The results in columns (1) and (2) imply that results for the difference between rural and urban poverty will mirror those for rural poverty. The closing of the gap between rural and urban poverty will be more rapid in more financially developed states pre-1977 and post-1990. In contrast between 1977 and 1990 it will be more backward states that are experiencing more rapid closing of their rural-urban poverty gaps. The results for aggregate poverty in column (3) also mirror those for rural poverty in column (1) and tell us that changes in rural poverty drive the aggregate pattern.

\footnotetext{
${ }^{25}$ We would expect there to be a lag between the opening of rural branches and their exerting any effect on rural poverty. This may explain why trend breaks in poverty lead those in branch expansion.
} 
In column (4) we see that the results for real daily male agricultural wages mirror those for rural poverty. Relative to financially developed states, agricultural wages in financially backward states grew more quickly only between 1977 and 1990. Column (4) serves as a robustness check on our poverty results, and points to an important route through which rural branch expansion may have reduced poverty. As a robustness check we show in column (5) that real wages for workers in registered manufacturing - which is mainly located in the urban sector - do not exhibit breaks in 1977 and 1990.

Table 5 considers different components of state output. Column (1) tells us that the relationship between state output per capita and initial financial development exhibited trend reversals in 1977 and 1990. Evaluated at the sample mean, and comparing states at the 25th and 75th percentile of the initial financial development distribution, the point estimates imply that, prior to 1977 annual increases in total output were 18.5 Rupees per capita lower in Madhya Pradesh than Tamil Nadu. Between 1977 and 1990, this trend was exactly reversed. Post 1990 the pattern is both reversed and magnified. In columns (2) and (3) we see that this pattern is not shared by primary sector output, or within this sector agricultural output. ${ }^{26}$ In column (4) we see that non-primary sector output drove the growth in total output, with the latter also exhibiting trend breaks in 1977 and 1990. Columns (5)-(8) focus in on the different components of the secondary sector. Initial financial development is uncorrelated with construction output and registered manufacturing output. Both these activities are concentrated in the urban sector. In contrast, column (7) shows that unregistered manufacturing and initial financial development are positively correlated until 1977, negatively between 1977 and 1990 and positively thereafter. The small businesses which make up unregistered manufacturing are important contributors to non-agricultural output in the rural sector (Visaria and Basant, 1994). Electricity, water and gas output is also negatively correlated with initial financial development after 1977 - this, possibly, also reflects the increase in rural non-agricultural activities. In column (9) we examine tertiary sector output. Between 1977 and 1990 tertiary sector output is lower in financially developed states. The opposite is true outside this period. Consistent with the thesis that the branch expansion program increased rural non-primary sector output, in column (10) we observe that while before 1977 financially developed states witnessed faster growth in the share of non-agricultural laborers in total unskilled rural labor, this trend is reversed between 1977 and $1987 .{ }^{27}$

\section{Robustness}

We interpret the observed trend breaks in the rural development outcomes and initial financial development relationship as reflecting the economic effects of rural branch expansion. We have provided evidence that these changes were caused by the 1:4 license rule, not by a reversal in the relationship between an Indian state's initial financial development and potential for economic growth after 1977. A different

\footnotetext{
${ }^{26}$ We have checked that the results are unaffected if we instead use agricultural output per hectare as our dependent variable

${ }^{27}$ As our data series ends in 1987 we cannot check for a 1990 trend break in employment
} 
source of potential omitted variable bias is poverty alleviation policies pursued by state governments. In our estimation framework this is a cause of concern if key political and policy variables which have the potential to influence rural development exhibited trend reversals in their relationship with initial financial development at the same points as rural branch expansion. Table 6 examines this possibility.

The Congress party which had been the dominant party in Indian politics since independence suffered a major electoral setback in $1977 .{ }^{28}$ A first concern is that the extent of state-wise ousting of Congress may have been systematically related to both the state's initial financial development and the subsequent choice of state-level public policies. Column (1), Table 6, however, finds no evidence of trend breaks in the relationship between the fraction of Congress legislators and initial financial development in 1977 or 1990. A second concern is that the 1977 political shock realigned political interests between the center and states with possible implications for resource flows. More backward states, for example, may have received more federal resources post-1977 as a result of this reconfiguration. ${ }^{29}$ However, in column (2) we find no evidence of trend breaks in the relationship between center-state alignment, as measured by whether the same party is in power in both places, and initial financial development.

The remainder of Table 6 considers an array of state-level anti-poverty policies. In the first few decades after independence land reform as a program for ushering in a just social order was an important item on almost every state government's policy agenda (Besley and Burgess, 2000; Banerjee, Gertler and Ghatak, 2002). Using state panel data 1958-1992 Besley and Burgess (2000) show that this land reform measure reduced rural poverty. We, however, in column (3) we find no evidence of trend breaks in the relationship the cumulative number of land reform acts passed by a state government bears to initial financial development. In column (4) we examine the relationship between the extent of public food distribution in a state and its initial financial development. ${ }^{30}$ The use of this program as a major poverty alleviation policy increased in the 1970s, with its incidence showing substantial variation across states (Besley and Burgess, 2002). However, again, we see no evidence of trend breaks. Finally, in columns (5) and (6) we directly consider the shares of government spending going to sectors which have the potential to impact rural development spending on education and health, and other development spending. We find no evidence of trend breaks for these variables.

These findings suggest that our identification strategy is reasonable and that rural branch expansion affected rural, but not urban, outcomes. We now turn to a more structural analysis of the impact of rural branches on rural development outcomes.

\footnotetext{
${ }^{28}$ This setback was linked to Indira Gandhi's decision to invoke a State of Emergency in 1975 as a means of remaining in power - a decision which tainted herself and her party. The proportion of Congress seats in state assemblies fell from 0.56 in 1976 to 0.25 in 1978.

${ }^{29}$ Dasgupta, Dhillon and Dutta [2001] show that state governments who were politically aligned with central government received greater transfers between 1968 and 1997.

${ }^{30}$ The Indian public food distribution system seeks to enhance the real incomes of poor households, and protect them against food shocks.
} 


\subsection{Instrumental Variables Evidence}

It is useful to start with the OLS results for the relationship between rural bank branch expansion and rural poverty. ${ }^{31}$ Column (1), Table 7 reports the results for rural head count ratio. The coefficient on the number of branches opened in rural unbanked locations is positive and significant. The positive relationship persists, but is statistically insignificant, once we include the interaction between a state's initial financial development and a time trend, and the vector of state initial conditions as additional covariates, column (2). ${ }^{32}$ Naively interpreted, these OLS results suggest that rural branch expansion increased rural poverty. However, an alternative 'program' based explanation is that the OLS estimate reflects the fact that poorer, less developed states attracted more rural branches between 1977 and 1990.

To take account of endogenous branch placement we use deviations in the trend relationship between initial financial development and rural branch expansion which were induced by license regime shifts in 1977 and 1990 as instruments for branch openings in rural unbanked locations. This is equivalent to a difference in difference estimator where we control for the systematic variation in branch expansion across states and time by including state and year fixed effects and a time trend interacted with initial financial development, and only consider the interaction between initial financial development and whether a state is in a treatment or control period as exogenous. Here, we have two 'control' periods (1961-1976 and 1990-2000) and one 'treatment' period (1977-1989).

The first stage regression is as in column (1), Table 3, and the second stage regression takes the form:

$$
y_{i t}=\alpha_{i}+\beta_{t}+\lambda B_{i t}^{R}+\eta_{1}\left([t-61] \times B_{i 61}\right)+\eta_{2}\left(P_{77} \times B_{i 61}\right)+\eta_{3}\left(P_{90} \times B_{i 61}\right)+u_{i t}
$$

where $P_{77} \times[t-76] \times B_{i 61}$ and $P_{90} \times[t-89] \times B_{i 61}$ are instruments for $B_{i t}^{R}$. This strategy assumes that the instruments affect rural development only via their effect on rural branch expansion. Table 6 showed that a range of political and policy variables which might affect rural development were orthogonal to our instruments. We also report over-identification tests of the validity of this assumption (Sargan (1958)).

Columns (3) - (5) of Table 7 report $I V$ estimates for poverty outcomes. The point estimate on rural branches in column (3) imply that one additional bank branch per 100,000 persons reduces rural poverty by 4.7 percent. ${ }^{33}$ Evaluated at the sample average, our results implies that rural branch expansion in India can explain a 15 percent reduction in the head count ratio. This finding lines up with the reduced form evidence but is in strict contrast with the $O L S$ results. In column (4) we find no evidence that rural branch expansion affected urban poverty. This increases our

\footnotetext{
${ }^{31}$ The OLS regression is of the form $y_{i t}=\alpha_{i}+\beta_{t}+\lambda B_{i t}^{R}+\varepsilon_{i t}$, where $y_{i t}$ is the outcome of interest and $B_{i t}^{R}$ is the cumulative number of branches opened in rural unbanked locations per capita.

${ }^{32}$ The coefficient on initial financial development time trend interaction term shows that rural poverty was throughout lower in more financially developed states.

${ }^{33}$ The point estimate for the marginal effect of rural banks on poverty is -4.74 , while the sample means for rural poverty and rural banked locations is 48.1 and 3.7 respectively. This gives an elasticity of rural poverty to rural branch expansion evaluated at the sample means of -0.36
} 
confidence that we are identifying the poverty impact of banking rural locations. Also given that our explanatory variable is a cumulative stock and that rural and urban poverty trend downwards this finding reduces concerns that we are capturing a trend effect. ${ }^{34}$ Column (5) summarizes the overall poverty impact of the rural branch expansion program. Opening a bank branch in one additional rural location per 100,000 persons lowers aggregate head count ratio by 4 percentage points.

In columns (6)-(8) we check whether our results for rural head count ratio are robust to alternative specifications. First, we check the robustness of our results to using a single control period. In column (6) we restrict the sample to the pretreatment (1961-1976) and treatment period (1977-1989) and use a single instrument $-P_{77} \times[t-76] \times B_{i 61}$. In column (7) we, instead, restrict the sample to the treatment and post-treatment periods (1977-2000). Here, our instrument for rural branch expansion is $P_{90} \times[t-89] \times B_{i 61}$. In both cases rural branch openings reduce rural poverty; however, the magnitude is larger in the second case. A possible interpretation is that during the control period 1990-2000 financial liberalization exerted independent effects on rural poverty. Second, we check the sensitivity of our findings to sample restrictions. We are using poverty estimates constructed by Ozler, Datt and Ravallion (1996) from Indian National Sample Survey household-level data. For years in which the survey was not conducted, the authors use weighted interpolation to construct poverty measures. In column (8) we show that our results for rural head count ratio are robust to restricting the regression only to years in which NSS surveys were conducted.

The operation of casual agricultural labor as a 'last resort' employment option underlines its link with poverty and a range of studies suggest that agricultural wages are an important and independent marker of rural welfare (Dreze and Mukherjee, 1991; Deaton and Dreze, 2002). In column (9) we see that opening a bank branch in an additional rural location increases agricultural wages. This may in part reflect a tightening of the agricultural labor market due to access to banks leading to rise in non-agricultural activities. Through this mechanism agricultural laborers may benefit from rural branch expansion even if they do not directly transact with rural banks. Given the debates surrounding the accuracy of the Indian poverty figures for the 1990s (see Deaton 2001; Deaton and Dreze 2002) it is also comforting to see the impact of rural branch expansion being felt on an independently collected, separate measure of welfare. In contrast, we find no evidence that factory wages are affected by rural branch expansion, column (10).

A key mechanism through which we may expect rural branch expansion to affect rural poverty is economic growth and diversification. Table 8 examines different elements of state domestic product in India. Rural branch expansion increases log state income per capita, column (1) and this occurs through effects on non-primary sector output. Columns (2) and (3) show that rural branch expansion exerts no direct effect on the primary sector output, or, within it, agricultural output. ${ }^{35}$ In

\footnotetext{
${ }^{34}$ Consistent with this we also find that rural branch expansion reduces the gap between rural and urban poverty - a variable which exhibits no clear trend over the period (see Figure 3).

${ }^{35}$ The absence of an effect in the agricultural sector is striking as raising agricultural productivity
} 
contrast, opening a bank branch in an additional rural location significantly raises secondary sector output - the effects in this sector are driven by unregistered manufacturing and electricity, water and gas. The estimated elasticities suggest a one to one correspondence between bank branch expansion and increases in unregistered manufacturing/electricity, water and gas output. The fact that we are finding significant effects for unregistered manufacturing which has a significant rural presence but not for registered manufacturing which is predominately urban is important. In column (9) we find a similar effect for the tertiary or services sector. Finally, rural branch expansion and the share of rural labor employed in non agricultural activities are positively associated. This is consistent with the thesis that a movement of labor out of agriculture contributed to the increase in agricultural wages. The relationship, however, is statistically insignificant once we cluster standard errors at the state-level. Taken together, these results suggest the rural poverty results we observe may be in part be accounted for by rural banking facilitating structural change in the rural economy.

\section{Robustness}

We conclude our empirical analysis with two types of robustness checks on our results. First, we show that increases in the share of rural credit and savings affect poverty and output outcomes in a manner similar to rural banks. This is evidence that the poverty and output impact of rural branch expansion was linked to increased financial intermediation in rural India. Second, we check the robustness of our findings to including as co-variates an array of time-varying policy and political variables which are known to affect poverty.

In Table 3 we saw that rural credit and rural saving shares exhibit trend reversals in their relationship with initial financial development in 1977 and, in the case of rural credit, in 1990 as well. This suggests that we can replicate the above IV procedure, where we, instead, measure financial intermediation by rural credit or savings share. The results are in Table 9. Columns (1)-(4) tell us that increases in rural credit and saving shares reduces rural, but not urban, poverty. A one percentage point increase in the share of credit disbursed by rural branches reduces rural poverty by 1.49 percent, while a one percentage point increase in rural saving reduces poverty by 2.2 percent. Columns (5)-(10) consider output variables. Columns (5) and (6) show that increases in rural credit and savings are associated with increases in total output. In columns (9) and (10) we see that these results are driven by increases increase in the rural credit and savings share leading to increase in non-primary output. In contrast, columns (7) and (8) show that primary output is unaffected.

In Table 10, we revisit the role of time-varying political and policy variables in driving poverty reductions in rural India. For expositional ease, we only present results for rural and urban head count ratio - however, all other results are also robust to the inclusion of these controls. In column (1) we include a cumulative

was a central objective of the program. Our results are, however, in line with previous findings form India (Binswanger et al, 1993, 1995). These authors find a very small, and mostly insignificant, effect of branch expansion on gross crop output. 
index of land reform acts passed by a state as an explanatory variable. In line with previous studies, we find increases in land reform reduces rural poverty. However, the effect of branch expansion on rural poverty is robust to this change in specification. In column (2) we add two state-level expenditure measures - spending on health and education, and other development spending. The latter category includes state spending on agriculture, rural development, irrigation, public works and community development programs. Both types of spending are important elements of a state's poverty reduction efforts. We, however, find that rural head count ratio is negatively correlated only with other development spending. We continue to find a negative relationship between rural branch expansion and rural poverty. And rural banks continue to exert a negative influence on rural poverty. In column (3) we directly control for the political make-up of state legislatures. Political parties in India differ with respect to both their commitment to redistribution, and the groups in whose favor they redistribute. We find the political make-up of state legislature does not affect the poverty outcomes and with the full set of additional controls included the effect of rural banks on rural poverty remains robust. Finally, in columns (4)-(6) we carry out the same exercise for urban head count ratio and find no impact of rural bank branches, land reform, development spending or political composition on urban poverty.

\section{Discussion}

A central question in the literature on finance and development is whether specific interventions can be identified which are capable of reducing poverty and promoting growth. Despite the existence of a large cross-country literature on finance and development, and a large theoretical and case study literature which suggests that credit market imperfections may constrain development we remain largely in the dark on the issue of whether and how to intervene. This paper uses data from the Indian social banking experiment program to shed some light on this issue. State led bank branch expansions have been an important means of expanding access to finance in low income countries in the post colonial period. Despite their importance, these programs have rarely been evaluated but are often condemned. An important criticism is that elite capture has rendered the bulk of state-led credit programs ineffective. This, in turn, has led to calls to replace banks with microfinance operations.

To address this lacuna in the literature we exploit the policy-driven nature of the Indian rural branch expansion program to evaluate its impact on rural poverty. Our central finding is that this program significantly reduced rural poverty, while leaving urban poverty unaffected. Moreover the magnitudes of the effects we find are large. Over our sample period aggregate poverty in India peaked in 1967 when 61 percent of the population was beneath the poverty line. This number fell to 31 percent by 2000. Evaluated at the sample mean, the coefficients in Tables 7 tell us that rural branch expansion can explain roughly half of this fall in rural poverty. This suggests that lack of access to finance may be an important reason why poor people stay poor. Our findings also go some way towards counteracting the widespread pessimism which 
surround state intervention in rural credit markets. Though we make no claim as to the transferability of our results to other settings these are, nonetheless, important results which suggest a need to reconsider rural banking as a mechanism for attacking poverty.

But how were the effects we observe on rural poverty achieved? A second contribution of the paper is to tease out some of the pathways. Our findings relate to an older literature which views structural change as key driver of economic development and poverty reduction (see Lewis, 1954; Kaldor, 1967; Banerjee and Newman, 1993). It is well documented that returns from non-primary sector activities typically exceed those from agriculture. We find that rural branch expansion was associated with increases in secondary and tertiary sector output. Within these sectors we identify unregistered or informal manufacturing and service sector as key beneficiaries of rural branch expansion. In a similar vein, within the unskilled rural labor force, rural banking increased non-agricultural employment at the expense of agricultural employment. This tightening of the agricultural labor market is also reflected in a rise in male agricultural wages. The program also appears to have enjoyed success in displacing the traditional moneylender (see Table 2). Throughout this period moneylender interest rates exceeded those charged by commercial banks (see Banerjee, 2001). Rural banks thus provided the rural populations access to cheaper credit than was previously available. ${ }^{36}$

Three features of the Indian social banking program appear to be important in accounting for its success in reducing poverty. First, the branch licensing rule succeeded in coercing commercial banks to open branches in backward rural locations. Without state coercion it is unlikely that the vast majority of India's rural poor would have been reached by banking services. Recent case study evidence also suggests that microfinance programs, which have been strongly promoted since the end of branch expansion in 1990, have been less successful in reaching backward areas (Ramachandran and Swaminathan, 2001). Second, it appears that rural banks managed to reach the rural poor. In Table 11 we use a pooled sample of 74,992 households from the 1983, 1987 and 1993 Employment/Unemployment rounds of National Sample Survey to examine how bank and moneylender debt incidence varies with land ownership (a good proxy of wealth in rural settings). We see that a landless household is about as likely to get a bank loan as a household with more than 2.5 acres of land. This distribution is markedly more uniform than that for moneylender borrowing. ${ }^{37}$ This evidence goes against the oft cited elite capture story (Adams et al, 1984). It also stands in stark contrast to those reported for other developing countries (e.g. Brazil

\footnotetext{
${ }^{36}$ Entry of a bank offering subsidized loans may also have exerted downward pressure on interest rates charged by moneylenders. The net direction of this effect is ex ante unclear (see Hoff and Stiglitz (1998)) and the lack of comparable and consistent data on moneylender interest rates prevents us from testing directly for this effect in our data.

${ }^{37}$ The story for credit flows is similar. At the height of the social banking program in 1985 marginal farmers (those with less than 2.5 acres of land) accounted for 12.2 percent of operational land holdings but 33 percent for bank short term agricultural credit. In contrast, large farmers (with more than 5 acres of land) controlled 73.7 percent of operational land holdings but only received 38 percent of the short term credit (Reserve Bank of India, 1989).
} 
and Costa Rica - see Besley 1995). It is also worth noting that microfinance programs in Bangladesh has often faced problems getting through to the poorest (Morduch, 1999). Third, commercial banks offered opportunities for households to save (Table 9). Savings accounts likely provided households with the means of accumulating capital which could be used to invest in various productive activities. Microfinance operations, in contrast, tend not to offer this option with the focus being on short term loans with frequent repayment.

It is, however, premature to conclude that social banking is the optimal policy response to the problem of widespread rural poverty. The branch expansion program ended in 1990 because of the heavy toll it exacted on the balance sheets of commercial banks. A key cause was high loan default rates - the average default rate for commercial banks during the 1980s stood at 42 percent (as a share of all loans due for repayment). Default rates were very similar across types of borrower - a finding consistent with poor monitoring of borrowers at all levels, and the fact that large scale loan defaults were very often politically condoned (Reserve Bank of India, 1989). Another factor contributing to high program costs was rural interest rate subsidies - during the 1980s the average interest rate on loans from rural branches was 11 percent as against 14 percent in urban branches.

From a policy design viewpoint, the fact that rural branches were a vehicle for costly redistribution of resources to rural areas is, in itself, not a damning criticism of the program. It is well-known that, in the presence of informational asymmetries, it may be optimal for a government that wishes to target resources to particular groups of citizens to undertake costly redistribution in order to best screen amongst citizens (Besley and Coate, 1992). It is clear that the Indian government sought to use the social banking program to redistribute resources to the rural poor. This suggests that the relevant policy question is, whether, in the class of costly redistributive programs, the social banking program was the most cost-effective.

The cost effectiveness comparison with microfinance is especially germane since the widespread perception that development banks are both costly and ineffective has led to widespread calls that they be replaced by microfinance operations. This is true both for India post-1990 and more broadly for low income countries as a whole (Morduch, 1999). ${ }^{38}$ Unfortunately, lack of comparable data on microfinance schemes in India makes a direct comparison infeasible. We can, however, get a 'back of the envelope' feel for the cost-benefit ratio for our program and compare this to ratios for microfinance programs in Bangladesh reported in Morduch (1999). Whilst not wishing to read too much into this exercise - due to the assumptions involved in the calculation and the problems of comparison across counties - it is, nonetheless, of interest to see whether our ratio lies in the ballpark of the microfinance ratios.

Our cost figures come from an evaluation of the program carried out by the Indian central bank in 1986 (Reserve Bank of India, 1989). For each 100 rupees of working

\footnotetext{
${ }^{38}$ The Indian central bank task force on microfinance (1997) stated, 'To achieve a process of change leading to empowerment of 7.5 million poor households, and more particularly of the women from these households, through strong and viable people's structures like Self help groups and microfinance institutions which draw strength and support from the banking system with the message that banking with the poor is a profitable business opportunity for both the poor and the banks'.
} 
funds the average rural branch received 11.5 rupees as interest on loans, paid 7.3 rupees as interest on deposits and had variable costs of 4.8 rupees (these include manpower and other expenses). The average rural branch, therefore, made a loss of 0.6 rupees per 100 rupees of working funds. The revenue position of a branch, however, was significantly worsened by the fact only 58 percent of loans were repaid. This increases the loss to 5.4 rupees per 100 rupees. We use our total deposits and total advances figures to compute the real loss per bank branch per capita in 1986 (498.13 rupees). To calculate benefits we take the coefficient $(0.08)$ - which we obtain from regressing rural banks per capita on log state income per capita in column (1) of Table 8 - and multiply it by the real state output per capita in 1986 (1020.2 rupees) to get a real benefit figure in 1986 of 183.45 per bank branch per capita. Dividing costs by benefits gives a cost benefit ratio of 2.72 . That is it costs 2.72 rupees to generate an additional rupee of state income via the social banking program.

This figure exceeds the cost benefit ratio of 0.91 that Khandker (1998) reports for improvements in household expenditure via borrowing by women from the Grameen Bank and of 1.48 for borrowing by men. Our figure of 2.72 is, however, in the ballpark of the ratios of 3.53 and 2.59 for borrowing from BRAC, the second largest microfinance lender in Bangladesh, by women and men, respectively (Khandker, 1998). And this is the case even when the default rate is at 42 percent. If we assume no default then our cost benefit ratio at 0.31 is well below even the Grameen ratios. If we take a default rate of 7.8 percent which is the average that Morduch (1999) reports for the Grameen Bank over the 1985-1996 period then our ratio rises to 0.75 which is close to the Grameen ratio for women. These comparisons, though rough, do bring out the fact that a key advantage of microfinance lies in its superior ability to enforce repayment of loans. ${ }^{39}$

This simple comparison, however, also suggests that no easy ranking of microfinance and social banking as regards cost effectiveness is possible. Both confer significant benefits as measured in terms of increased expenditure or income. However, both types of schemes also incur significant subsidies. The demonstrated advantage of microfinance in terms of repayment needs to be balanced against disadvantages in terms of reaching the poorest individuals and localities. ${ }^{40}$ One clear thing that we do learn from this paper is that coercion is needed to expand formal credit into backward rural areas and to force banks to lend to poorer individuals. And here government may have some advantages in terms of coordination, legal powers and resources. There is also the issue of whether providing a savings function is important. The fact that a number of microfinance operations are evolving into banks which offer this service suggests that it may be.

In 1998 India accounted for a third of the people in the developing world living below the dollar a day poverty line. That the rural branch expansion managed to

\footnotetext{
${ }^{39} \mathrm{It}$ is also clear that there is scope for banks to increase lending rates as a means of reducing costs as even microfinance operations charge higher nominal rates than those on offer from rural banks. The problem with this strategy as Morduch (1999) points out is that one runs the risk of excluding the poor.

${ }^{40}$ Reaching the poorest in rural areas who are often involved in subsistence agriculture and who cannot make frequent repayments, for example, is problematic.
} 
make a significant dent on the numbers in poverty during the 1961-2000 period is the key finding of this paper. It suggests that expanding access to finance in poor, rural settings can generate significant social returns. It also points to the need to identifying specific interventions which facilitate the adoption of new production activities and lead to structural change, growth and poverty. Our analysis is limited to a specific policy episode. Whether rural branch expansion would be effective in other settings and whether resources would be better spent on other types of programs remain open questions. Nonetheless it does appear to be an opportune moment to reexamine whether rural banks can be harnessed to attack rural poverty. 


\section{References}

[1] Adams, Dale, Graham, Douglas and J.D. Von Pischke, [1984], "Undermining Rural Development with Cheap Credit" (Boulder: Westview Press).

[2] Aghion, P. and P. Bolton [1997], "A Theory of Trickle-Down Growth and Development", Review of Economic Studies 64(2): 151-72

[3] Almond, Douglas, Kenneth Chay and Michael Greenstone [2002], "Civil Rights, The War on Poverty and Black-White Convergence in Infant Mortality in Rural Mississipi", mimeo, University of Chicago.

[4] Balachandran, Gopal, [1998], "The Reserve Bank of India, 1951-1967" (Mumbai: Reserve Bank of India; New York : Oxford University Press).

[5] Banerjee, Abhijit, [2001], "Contracting Constraints, Credit Markets and Economic Development" mimeo MIT.

[6] Banerjee, Abhijit V., Gertler, Paul J. and Maitreesh Ghatak, [2002], "Empowerment and Efficiency: Tenancy Reform in West Bengal", Journal of Political Economy , 110(2), 239-80.

[7] Banerjee, Abhijit and Andrew Newman, [1993], "Occupational Choice and the Process of Development", Journal of Political Economy, 101, 274-298.

[8] Bencivenga, Valerie and Bruce D. Smith, [1991], "Financial Intermediation and Endogenous Growth" Review of Economic Studies 58, 195-209.

[9] Bernanke, Ben and Mark Gertler, [1990], "Financial Fragility and Economic Performance", Quarterly Journal of Economics, 105.

[10] Bertrand, Marianne, Esther Duflo, and Sendhil Mullainathan, [2002], "How Much Should We Trust Differences in Differences Estimates", NBER Working Paper No. 8841.

[11] Besley, Timothy, [1995], "Saving, Credit and Insurance," in Jere Behrman and T.N. Srinivasan (ed) Handbook of Development Economics, Vol. IIIa Amsterdam: North Holland.

[12] Besley, Timothy and Robin Burgess, [2000], "Land Reform, Poverty and Growth: Evidence from India", Quarterly Journal of Economics, 115 (2), 389-430.

[13] Besley, Timothy and Robin Burgess, [2002], "The Political Economy of Government Responsiveness: Theory and Evidence from India", Quarterly Journal of Economics, 117 (4).

[14] Besley, Timothy and Stephen Coate, [1992], "Workfare versus Welfare: Incentive Arguments for Work Requirements in Poverty Alleviation Programs" American Economic Review, 82, (1) 249-261. 
[15] Binswanger, Hans, and Khandker, Shahidur, [1995], "The impact of formal finance on the rural economy of India ," Journal of Development studies32(2):234262.

[16] Binswanger, Hans, Khandker, Shahidur and Mark Rozenzweig, [1993], "How Agriculture and Financial Institutions Affect Agricultural Output and Investment in India," Journal of Development Economics.

[17] Braverman, A and JL Guasch [1986], "Rural Credit Markets and Institutions in Developing Countries: Lessons for Policy Analysis from Practice and Modern Theory," World Development, 14.

[18] Burgess, Robin and Anthony Venables [2003], "Towards a Microeconomics of Growth". Forthcoming Annual World Bank Conference on Development Economics.

[19] Chenery, Hollis B., Moshe Syrquin and and Sherman Robinson [1986] "Industrialization and Growth: A Comparative Study" (Oxford: Oxford University Press)

[20] Dasgupta, Sugato, Amrita Dhillon and Bhaskar Dutta [2001], "The Political Economy of Centre-State resource Transfer in India," mimeo, Warwick.

[21] Deaton, Angus [2001]: “Adjusted Indian Poverty Estimates 1999-2000" mimeo, Princeton.

[22] Deaton, Angus and Jean Dreze [2002]: "Poverty and Inequality in India: A Re-examination" Economic and Political Weekly, September 7.

[23] Dehejia, Rajeev and Adriana Lleras-Muney, [2002] "Why Does Financial Development Matter? The United States from 1900 to 1940", mimeo Columbia University

[24] Desai, Vasant, [1987], "Indian banking : Nature and Problems" (Bombay : Himalaya Pub. House).

[25] Dreze, J. and Mukherjee, A. [1991]: "Labour Contracts in Rural India: Theory and Evidence" in S. Chakravarty (ed) The Balance between Industry and Agriculture in Economic Development (New York)

[26] Duflo, Esther [2001], "Schooling and Labor Market Consequences of School Construction in Indonesia: Evidence from an Unusual Policy Experiment" American Economic Review.

[27] Eastwood, Robert and Renu Kohli [1999], "Directed Credit and Investment in Small-Scale Industry in India: Evidence from Firm-Level Data, 1965-1978" Journal of Development Studies, 35 (4)

[28] Government of India [1991], "Report of the Committee on the Financial Sector" chairman M. Narsimhan, Ministry of Finance, Delhi . 
[29] Gerschenkron, Alexander [1962], Economic Backwardness in Historical Perspective Harvard University Press, Cambridge.

[30] Greenwood, J. and B. Jovanovic, [1990], "Financial Development, Growth and the Distribution of Income" Journal of Political Economy, 98(5), 1076-1107.

[31] Hoff, Karla and Joseph Stiglitz, [1998], "Moneylenders and Bankers: Price Increasing Subsidies in a Monopolistically Competitive Market" Journal of Development Economics 55: 485-518.

[32] Jayaratne, Jith and Philip E. Strahan, [1996], "The Finance-Growth Nexus: Evidence from Bank Branch Deregulation" Quarterly Journal of Economics, 111(3), 639-70.

[33] Kaldor, Nicholas [1967], "Strategic Factors in Economic Development" (Ithaca: Cornell University Press)

[34] Khandker, Shahidur R. [1998] "Fighting poverty with microcredit : experience in Bangladesh", New York, Oxford University Press.

[35] King, Robert and Levine, Ross [1993]: "Finance and Growth: Schumpeter might be Right" Quarterly Journal of Economics, CVIII, no. 3 August, 717-738.

[36] La Porta, Rafael, Florencio Lopez de Silanes and Andrei Shleifer, [2002], "Government Ownership of Banks" Journal of Finance, February.

[37] Levine, Ross and Sara Zervos, [1998], "Stock Markets, Banks, and Economic Growth" American Economic Review, 88(3), 537-58.

[38] Lewis, W.A., [1954], "Economic Development with Unlimited Supplies of Labour" The Manchester School of Economic and Social Studies 22, 139-191.

[39] Morduch, Jonathan [1999]," The Microfinance Promise", Journal of Economic Literature, Vol. XXXVII, 1569-1614

[40] Nair, Tara , [2000], "Rural Financial Intermediation and Commercial Banks: Review of Recent Trends" Economic and Political Weekly, January 29.

[41] Ozler, B. Datt, G. and Ravallion, M., [1996], "A Data Base on Poverty and Growth in India" mimeo, World Bank.

[42] Rajan, Raghuram G. and Luigi Zingales, [1998] "Financial Dependence and Growth", American Economic Review 88(3), 559-86.

[43] Reserve Bank of India, [1954], 'All-India rural credit survey: report', Report of the Committee of Direction of the All India Rural Credit Survey, Mumbai.

[44] Ramachandran, V.K. and Madhura Swaminathan, [2001], "Does Informal Credit Provide Security? Rural Banking Policy in India" mimeo International Labour Office, Geneva. 
[45] Reserve Bank of India, [1989], 'A Review of the Agricultural Credit System in India', Report of the Agricultural Credit Review Committee, Mumbai

[46] Reserve Bank of India, [1997], Basic Statistical Returns for Commercial Banks, Mumbai.

[47] Reserve Bank of India, [1998], Banking Statistics 1972-1995, Mumbai.

[48] Reserve Bank of India, [2000], Directory of Commercial Bank Offices in India (Volume 1), Mumbai.

[49] Sapienza, Paola, [2003], "The Effects of Government Ownership on Bank Lending" Journal of Financial Economics forthcoming.

[50] Sargan, John Denis, [1958], "The Estimation of Economic Relationships Using Instrumental Variables" Econometrica XXVI , 393-415

[51] Schumpeter, Joseph, [1934], The Theory of Economic Development: An Inquiry into Profits, Capital, Interest, and the Business Cycle (Cambridge: Harvard University Press)

[52] Townsend, Robert M. and Kenichi Ueda [2001], "Transitional Growth with Increasing Inequality and Financial Deepening" mimeo University of Chicago.

[53] Visaria, Pravin and Rakesh Basant, [1994], "Non-Agricultural Employment in India: Trends and Prospects" (New Delhi, Sage Publications).

[54] Zinman, Jonathan [2002], "The Efficacy and Efficiency of Credit Market Interventions: Evidence from the Community Reinvestment Act", mimeo, MIT. 


\section{Data Appendix}

The data used in the paper come from a wide variety of sources. ${ }^{41}$ The data cover the sixteen main Indian states, and unless mentioned otherwise the period 1961-2000. ${ }^{42}$ Haryana split from the state of Punjab in 1965 and enters our sample in 1965.

Deflators and Population Variables expressed in real terms are deflated using the Consumer Price Index for Agricultural Laborers (CPIAL) and Consumer Price Index for Industrial Workers (CPIIW). These are drawn from the Indian Labor Handbook, the Indian Labor Journal, the Indian Labor Gazette and the Reserve Bank of India Report on Currency and Finance. Ozler, Datt and Ravallion [1996] have further corrected CPIAL and CPIIW to take account of inter-state cost of living differentials and have also adjusted CPIAL to take account of rising firewood prices. The reference period for the deflator is October 1973-March 1974. Post-1994 we update this series using the Indian Labor Journal (CPIIW) and the Monthly Abstract of Statistics (CPIAL). Post-1995 we do not adjust for firewood prices. We normalize all series by the state's population in 1961, which comes from the decennial census [Census of India, Registrar General and Census Commissioner, Government of India]. The number of rural locations in a state in 1961 is also from this source - the census terms a location as rural if it has a population of less than 10,000. In line with this, we include all towns with a population less than 10,000 and all villages with population between 2,000 and 10,000.

Banking data refers to scheduled commercial banks. ${ }^{43}$ The bank branch data is from Reserve Bank of India [2000] which uses the census definition of rural locations. The initial financial development of a state is the number of bank branches in that state in 1961 per 10,000 population. A location is categorized as banked if it has at least one branch of any commercial or cooperative bank. Two bank branch variables are defined: the number of branches opened in rural locations with no prior presence of commercial banks (rural unbanked locations), and the number of branches opened in already banked locations. Rural credit share is the proportion of total advances outstanding of commercial banks which are disbursed by rural branches. Rural saving share is similarly defined. Share of priority sector lending is the fraction of bank credit going to the priority sectors. These three variables are available from 19692000. Cooperative lending share is the fraction of total bank and cooperative credit which is accounted for by primary agricultural cooperatives. Data on bank credit and saving is from the Reserve Bank of India publication Statistical Tables Relating to Banks in India.

\footnotetext{
${ }^{41}$ The data-set builds on Ozler, Datt and Ravallion [1996] which collects published data on poverty, output, wages, price indices and population to construct a consistent panel data set on Indian states [1958-1992]. We are grateful to Martin Ravallion for providing the data, and to Gaurav Datt for answering various queries. We have added information on bank location and credit outcomes, state income, rural employment, infrastructure and public finances of Indian states.

${ }^{42}$ The states in the sample are: Andhra Pradesh, Assam, Bihar, Gujarat, Haryana, Jammu and Kashmir, Karnataka, Kerala, Madhya Pradesh, Maharashtra, Orissa, Punjab, Rajasthan, Tamil Nadu, Uttar Pradesh and West Bengal

${ }^{43}$ This category includes (1) State Bank of India and its associates, (2) Nationalized banks, (3) Regional rural banks, (4) Private sector banks, and (5) Foreign banks.
} 
Poverty figures are for rural and urban areas of India's 16 major states. 1961-1992 figures were put together by Ozler, Datt and Ravallion [1996], and the 1993-2000 update which uses the same methodology was provided by Gaurav Datt. Data is missing for Jammu-Kashmir after 1991, giving 627 observations. These measures are based on 25 rounds of the National Sample Survey (NSS) which span this period. 44 The NSS rounds are also not evenly spaced: the average interval between the midpoints of the surveys ranges from 0.9 to 5.5 years. Surveys were carried out in the following years 1961, 1962, 1963, 1965, 1966, 1967, 1968, 1969, 1970, 1971, 1973, 1974, 1978, 1983, 1987, 1988, 1990, 1991, 1992, 1993, 1994, 1995, 1996, 1997, 2000. Because other data is typically available on a yearly basis weighted interpolation has been used to generate poverty measures for years where there was no NSS survey. The poverty lines recommended by the Planning Commission [1993] are used and are as follows. The rural poverty line is given by a per capita monthly expenditure of Rs. 49 at October 1973-June 1974 all-India rural prices. The urban poverty line is given by a per capita monthly expenditure of Rs. 57 at October 1973-June 1974 all-India urban prices. See Datt [1995] for more details on the rural and urban cost of living indices and on the estimation of the poverty measures. The head count index is estimated from the grouped distributions of per capita expenditure published by the $\mathrm{NSS}^{45}$, using parameterized Lorenz curves using a methodology detailed in Datt and Ravallion [1992].

Wage Agricultural wages data is from the Agricultural Wages in India (Ministry of Agriculture, Government of India) and deflated using the CPIAL. The data spans the period 1961-1998. It is unavailable for Jammu and Kashmir and after 1992 for Kerala. No separate wage data is available for the state of Haryana. Data is missing for Orrissa in 1968. This gives a total of 545 observations. Factory wages data spans 1961-1995. These are defined to include all remunerations capable of being expressed in monetary terms plus the imputed value of benefits in kind and also payable more or less regularly in each pay period to factory employees. The wages are expressed in terms of gross value i.e. before deduction for fines, damages, taxes, provident funds, employee's state insurance contribution etc. The source is the Annual Survey of Industries and are expressed in log real terms per employee.

State output figures come from Estimates of State Domestic Product published by Department of Statistics, Ministry of Planning, Government of India. These span the period 1961-1997. Output variables are expressed in log per capita terms. The sector-wise breakdown of total output is done under the National Industrial Classification System (NIC) which conforms with the International Standard Industrial Classification System (ISIC).

Employment data come from the 1963-65, 1974-75, 1977-78, 1983, and 1987-88

\footnotetext{
${ }^{44}$ For 11 states (Andhra Pradesh, Assam, Bihar, Karnataka, Kerala, Madhya Pradesh, Orissa, Rajasthan, Tamil Nadu, Uttar Pradesh, and West Bengal) all rounds have been covered. Because Haryana only appears as a separate state from Punjab in 1965 we have adopted the including separate series for these two states from this date onwards.

${ }^{45}$ Reports from the National Sample Survey Organization, Department of Statistics, Ministry of Planning, Government of India and Sarvekshena, Journal of the National Sample Survey Organization, Department of Statistics, Ministry of Planning, Government of India.
} 
issues of the Rural Labour Enquiry, National Sample Survey Office, Government of India. The data refer to rural labor households, where rural labor is defined as manual paid activities as opposed to non-manual employment or self-employment.

Policy variables. Education and health expenditure data are from Public Finance Statistics (Ministry of Finance, Government of India) and Report on Currency and Finance,(RBI) 1961-1999. The land reform variable is the cumulative number of land reform acts undertaken by a state, and is from Besley and Burgess 2001. Public food distribution is food grains measured in tonnes distributed via the Public Food Distribution system (Bulletin on Food Statistics, Ministry of Food and Agriculture, Government of India), 1961-1993. It is expressed in per capita terms.

Politics variables. Number of seats won by different political parties is from Butler, Lahiri and Roy, 1991, and is updated for 1992-2000 from the Election Commission of India state election reports. Center-state alignment variable is from Dasgupta, Dhillon and Dutta 2001, 1961-1995. ${ }^{46}$

Household debt data The data used in Table 11 is from the rural labor household files for the National Sample Survey quinquennial Employment and Unemployment rounds for 1983, 1987 and 1993. 
TABLE 1 -- SUMMARY OF MAIN VARIABLES

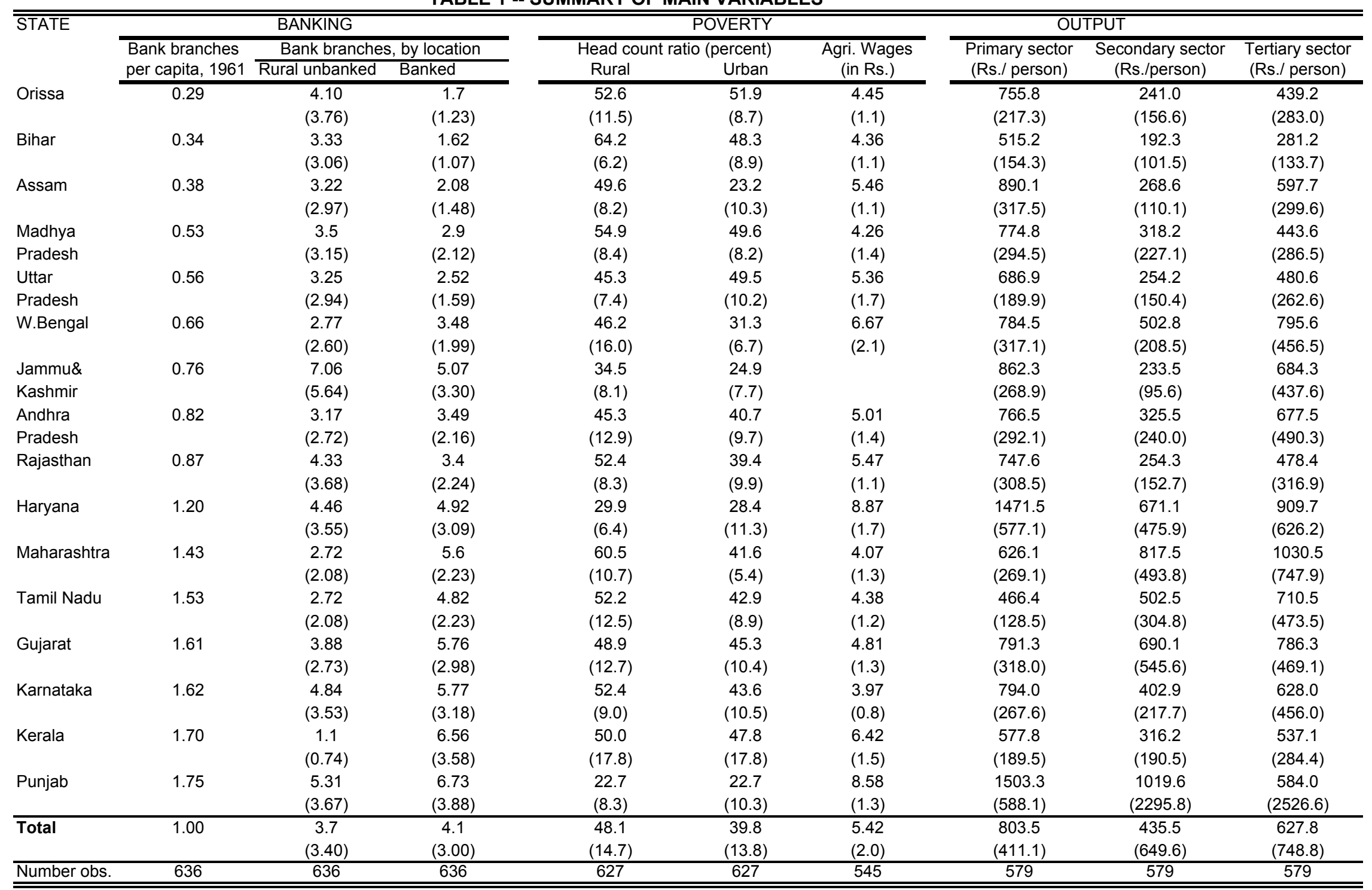

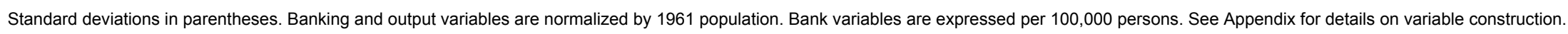

The data covers 16 major states, 1961-2000. Haryana enters the sample in 1965 giving a total of 636 possible observations. The final row gives variable-wise observations available. 
TABLE 2: SHARE OF RURAL HOUSEHOLD DEBT HELD BY DIFFERENT CREDITORS (percentage)

\begin{tabular}{|c|c|c|c|c|c|}
\hline \multirow[t]{2}{*}{ YEAR } & \multicolumn{2}{|c|}{ INSTITUTIONAL SOURCES } & \multicolumn{2}{|c|}{ NON-INSTITUTIONAL SOURCES } & \multirow[t]{2}{*}{ OTHERS } \\
\hline & Banks & Cooperatives & Relatives and Friends & Moneylenders & \\
\hline 1951 & 1.1 & 4.6 & 14.4 & 68.6 & 9.3 \\
\hline 1961 & 0.3 & 10.4 & 5.8 & 60.9 & 22.6 \\
\hline 1971 & 2.4 & 20.1 & 13.8 & 36.9 & 26.8 \\
\hline 1981 & 28.6 & 28.6 & 9 & 16.9 & 16.9 \\
\hline 1991 & 29 & 18.6 & 6.7 & 15.7 & 30 \\
\hline
\end{tabular}

Loans from relatives and friends refer to interest-free non-institutional loans. 'Others' category includes loans from government, landlords and traders/commissioners. The data source for 1951 is the "All India Rural Credit Survey", and for all subsequent years "All India Debt and Investment Surveys". 
TABLE 3: BANKING AS A FUNCTION OF INITIAL FINANCIAL DEVELOPMENT

\begin{tabular}{|c|c|c|c|c|c|c|}
\hline & \multicolumn{2}{|c|}{ Number branches, by location: } & \multirow{2}{*}{$\begin{array}{c}\text { Rural bank credit } \\
\text { share }\end{array}$} & \multirow{2}{*}{$\begin{array}{c}\text { Rural bank saving } \\
\text { share }\end{array}$} & \multirow{2}{*}{$\begin{array}{l}\text { Priority sector } \\
\text { credit share }\end{array}$} & \multirow{2}{*}{$\begin{array}{l}\text { Cooperative } \\
\text { credit share }\end{array}$} \\
\hline & Rural unbanked & Banked & & & & \\
\hline & $(1)$ & $(2)$ & $(3)$ & $(4)$ & $(5)$ & $(6)$ \\
\hline Number of bank branches in 1961 & $0.07^{* *}$ & $0.14^{* \star \star}$ & 0.17 & -0.02 & -0.08 & 0.41 \\
\hline per capita *(1961-2000) trend & $(0.03)$ & $(0.01)$ & $(0.20)$ & $(0.23)$ & $(0.62)$ & $(0.33)$ \\
\hline $\begin{array}{l}\text { Number of bank branches in } 1961 \\
\text { per capita*(1977-2000) trend }\end{array}$ & $\begin{array}{c}-0.25^{\star * *} \\
(0.03)\end{array}$ & $\begin{array}{c}-0.07^{* * *} \\
(0.02)\end{array}$ & $\begin{array}{l}-1.09^{* *} \\
(0.43)\end{array}$ & $\begin{array}{c}-0.82^{* * *} \\
(0.25)\end{array}$ & $\begin{array}{c}0.08 \\
(0.86)\end{array}$ & $\begin{array}{l}-0.02 \\
(0.41)\end{array}$ \\
\hline $\begin{array}{l}\text { Number of bank branches in } 1961 \\
\text { per capita*(1990-2000) trend }\end{array}$ & $\begin{array}{l}0.17^{* * *} \\
(0.04)\end{array}$ & $\begin{array}{l}0.10^{* *} \\
(0.04)\end{array}$ & $\begin{array}{l}0.89^{* * *} \\
(0.26)\end{array}$ & $\begin{array}{l}0.39^{*} \\
(0.20)\end{array}$ & $\begin{array}{l}-0.18 \\
(0.33)\end{array}$ & $\begin{array}{c}0.02 \\
(0.99)\end{array}$ \\
\hline Post-1976 dummy* $(1977-2000)$ trend & $\begin{array}{c}0.34 \\
(0.25)\end{array}$ & $\begin{array}{l}0.53^{* *} \\
(0.19)\end{array}$ & $\begin{array}{l}-0.30 \\
(1.49)\end{array}$ & $\begin{array}{l}-0.16 \\
(0.77)\end{array}$ & $\begin{array}{l}-3.36 \\
(2.40)\end{array}$ & $\begin{array}{l}-3.64 \\
(2.22)\end{array}$ \\
\hline Post-1989 dummy* ${ }^{*}(1990-2000)$ trend & $\begin{array}{l}-0.24 \\
(0.15)\end{array}$ & $\begin{array}{l}-0.40^{* * *} \\
(0.10)\end{array}$ & $\begin{array}{c}2.03 \\
(1.52)\end{array}$ & $\begin{array}{c}0.28 \\
(0.55)\end{array}$ & $\begin{array}{l}-0.04 \\
(1.85)\end{array}$ & $\begin{array}{l}-3.15 \\
(2.61)\end{array}$ \\
\hline State and year dummies & YES & YES & YES & YES & YES & YES \\
\hline Other controls & YES & YES & YES & YES & YES & YES \\
\hline Adjusted R-squared & 0.96 & 0.98 & 0.91 & 0.92 & 0.88 & 0.83 \\
\hline F-test 1 & $\begin{array}{c}16.87 \\
{[0]}\end{array}$ & $\begin{array}{c}8.97 \\
{[0]}\end{array}$ & $\begin{array}{c}12.8 \\
{[0]}\end{array}$ & $\begin{array}{c}25.67 \\
{[0]}\end{array}$ & $\begin{array}{c}0 \\
{[0.99]}\end{array}$ & $\begin{array}{c}5.75 \\
{[0.02]}\end{array}$ \\
\hline F-test 2 & 0.49 & 27.22 & 0.03 & 10.35 & 1.79 & 0.17 \\
\hline & {$[0.49]$} & [0] & {$[0.86]$} & [0] & {$[0.20]$} & {$[0.68]$} \\
\hline Number observations & 636 & 636 & 512 & 512 & 512 & 491 \\
\hline
\end{tabular}

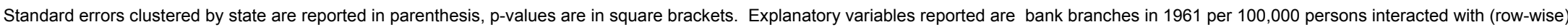

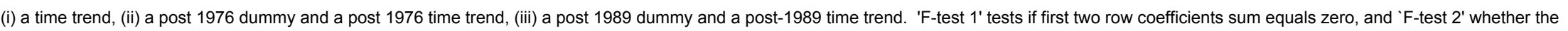

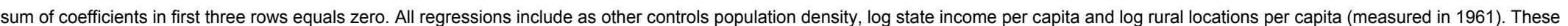

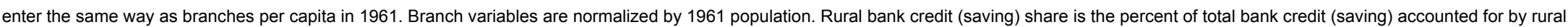

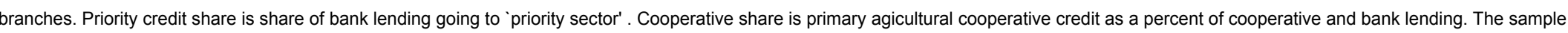

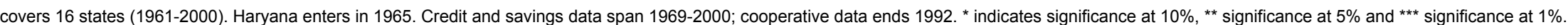


TABLE 4: BANK BRANCH EXPANSION AND POVERTY: REDUCED FORM EVIDENCE

\begin{tabular}{|c|c|c|c|c|c|}
\hline & \multicolumn{3}{|c|}{ Head count ratio } & \multicolumn{2}{|c|}{ Wage } \\
\hline & Rural & Urban & Aggregate & Agricultural & Factory \\
\hline & $(1)$ & $(2)$ & $(3)$ & $(4)$ & $(5)$ \\
\hline Number of bank branches in 1961 & $-0.77^{* * *}$ & -0.27 & $-0.71^{* * *}$ & -0.003 & 0.01 \\
\hline per capita *(1961-2000) trend & $(0.23)$ & $(0.24)$ & $(0.22)$ & $(0.006)$ & $(0.02)$ \\
\hline Number of bank branches in 1961 & $1.15^{\star *}$ & 0.15 & $0.99^{* * *}$ & $-0.01^{*}$ & -0.01 \\
\hline per capita*(1977-2000) trend & $(0.42)$ & $(0.26)$ & $(0.33)$ & $(0.008)$ & $(0.02)$ \\
\hline Number of bank branches in 1961 & $-1.15^{* * *}$ & -0.31 & $-1.04^{* * *}$ & $0.04^{* *}$ & -0.02 \\
\hline per capita*(1990-2000) trend & $(0.34)$ & $(0.38)$ & $(0.31)$ & $(0.02)$ & $(0.01)$ \\
\hline \multirow[t]{2}{*}{ Post-1976 dummy* (1977-2000) trend } & $-3.77^{*}$ & -2.76 & $-3.53^{* *}$ & $0.08^{*}$ & 0.04 \\
\hline & $(1.94)$ & $(2.29)$ & $(1.71)$ & $(0.04)$ & $(0.05)$ \\
\hline & $(2.39)$ & $(0.96)$ & $(1.82)$ & $(0.05)$ & $(0.02)$ \\
\hline State and year dummies & YES & YES & YES & YES & YES \\
\hline Other controls & YES & YES & YES & YES & YES \\
\hline Adjusted R-squared & 0.84 & 0.91 & 0.88 & 0.9 & 0.72 \\
\hline \multirow[t]{2}{*}{ F-test 1} & 1.5 & 0.37 & 1.76 & 23.95 & 0.23 \\
\hline & {$[0.24]$} & {$[0.55]$} & {$[0.20]$} & [0] & [0.63] \\
\hline \multirow[t]{2}{*}{ F-test 2} & 2.97 & 3.95 & 4.15 & 1.88 & 6.07 \\
\hline & {$[0.10]$} & {$[0.06]$} & {$[0.05]$} & {$[0.19]$} & {$[0.02]$} \\
\hline Number observations & 627 & 627 & 627 & 545 & 553 \\
\hline
\end{tabular}

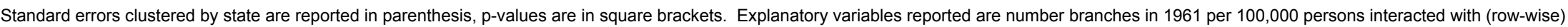

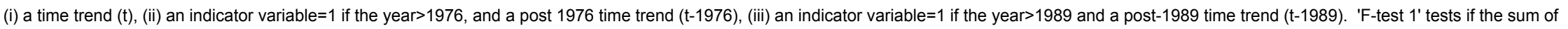
coefficients for first two rows equals zero, and 'F-test 2 ' whether sum of coefficients in first three rows equals zero. Other controls are population density, log state income per capita and log rural

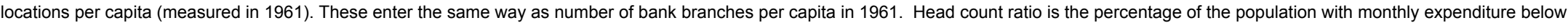

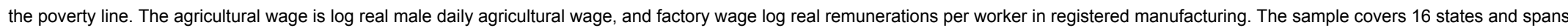
1961-2000. Haryana enters in 1965. Differences in sample size are due to missing data, details are in Appendix. ${ }^{*}$ indicates significance at $10 \%,{ }^{* *}$ significance at $5 \%$ and ${ }^{* \star *}$ significance at $1 \%$. 
TABLE 5: BANK BRANCH EXPANSION AND OUTPUT: REDUCED FORM EVIDENCE

\begin{tabular}{|c|c|c|c|c|c|c|c|c|c|c|}
\hline & \multirow{3}{*}{$\begin{array}{c}\begin{array}{c}\text { State } \\
\text { output }\end{array} \\
\text { Total }\end{array}$} & \multicolumn{2}{|c|}{$\begin{array}{c}\text { Primary sector } \\
\text { output }\end{array}$} & \multirow{3}{*}{$\begin{array}{c}\begin{array}{c}\text { Non-prima } \\
\text { ry output }\end{array} \\
\text { Total }\end{array}$} & \multicolumn{4}{|c|}{ Secondary sector output } & \multirow{3}{*}{$\begin{array}{c}\text { Tertiary } \\
\text { output } \\
\text { Total }\end{array}$} & \multirow{3}{*}{$\begin{array}{c}\begin{array}{c}\text { Employ- } \\
\text { ment }\end{array} \\
\text { Rural non- } \\
\text { agricultura }\end{array}$} \\
\hline & & Total & Agriculture & & \multirow{2}{*}{$\begin{array}{l}\text { Construc- } \\
\text { tion }\end{array}$} & \multicolumn{2}{|c|}{ Manufacturing } & \multirow{2}{*}{$\begin{array}{l}\text { Electricity, } \\
\text { water, gas }\end{array}$} & & \\
\hline & & & & & & Registered & Unregistered & & & \\
\hline & (1) & $(2)$ & $(3)$ & $(4)$ & $(5)$ & $(6)$ & $(7)$ & $(8)$ & $(9)$ & $(10)$ \\
\hline $\begin{array}{l}\text { Number of bank branches in } 1961 \\
\text { per capita *(1961-2000) trend }\end{array}$ & $\begin{array}{c}0.01^{* *} \\
(0.002)\end{array}$ & $\begin{array}{l}-0.01 \\
(0.01)\end{array}$ & $\begin{array}{l}-0.01^{*} \\
(0.004)\end{array}$ & $\begin{array}{l}0.02^{* \star *} \\
(0.004)\end{array}$ & $\begin{array}{l}-0.02 \\
(0.03)\end{array}$ & $\begin{array}{c}0.01 \\
(0.01)\end{array}$ & $\begin{array}{l}0.03^{*} \\
(0.01)\end{array}$ & $\begin{array}{c}0.01 \\
(0.01)\end{array}$ & $\begin{array}{l}0.02^{* *} \\
(0.01)\end{array}$ & $\begin{array}{l}0.06^{* * *} \\
(0.01)\end{array}$ \\
\hline $\begin{array}{l}\text { Number of bank branches in } 1961 \\
\text { per capita*(1977-2000) trend }\end{array}$ & $\begin{array}{l}-0.02^{* * *} \\
(0.004)\end{array}$ & $\begin{array}{l}-0.01 \\
(0.01)\end{array}$ & $\begin{array}{l}-0.01 \\
(0.01)\end{array}$ & $\begin{array}{l}-0.03^{* * *} \\
(0.004)\end{array}$ & $\begin{array}{c}0.02 \\
(0.04)\end{array}$ & $\begin{array}{l}-0.01 \\
(0.01)\end{array}$ & $\begin{array}{l}-0.06^{*} \\
(0.03)\end{array}$ & $\begin{array}{c}-0.07^{* * *} \\
(0.02)\end{array}$ & $\begin{array}{c}-0.03^{* * *} \\
(0.01)\end{array}$ & $\begin{array}{l}-0.06^{* *} \\
(0.02)\end{array}$ \\
\hline $\begin{array}{l}\text { Number of bank branches in } 1961 \\
\text { per capita*(1990-2000) trend }\end{array}$ & $\begin{array}{l}0.03^{* * *} \\
(0.01)\end{array}$ & $\begin{array}{l}0.02^{* *} \\
(0.01)\end{array}$ & $\begin{array}{l}0.02^{*} \\
(0.01)\end{array}$ & $\begin{array}{l}0.03^{* * *} \\
(0.01)\end{array}$ & $\begin{array}{c}0.02 \\
(0.02)\end{array}$ & $\begin{array}{c}0.05 \\
(0.03)\end{array}$ & $\begin{array}{l}0.04^{*} \\
(0.02)\end{array}$ & $\begin{array}{l}-0.04 \\
(0.05)\end{array}$ & $\begin{array}{l}0.02^{* * *} \\
(0.01)\end{array}$ & \\
\hline $\begin{array}{l}\text { Post-1976 dummy* (1977-2000) } \\
\text { trend }\end{array}$ & $\begin{array}{c}0.06 \\
(0.03)\end{array}$ & $\begin{array}{l}0.13^{* *} \\
(0.05)\end{array}$ & $\begin{array}{l}0.14^{* * *} \\
(0.05)\end{array}$ & $\begin{array}{l}-0.02 \\
(0.03)\end{array}$ & $\begin{array}{c}0.05 \\
(0.12)\end{array}$ & $\begin{array}{c}0.12 \\
(0.08)\end{array}$ & $\begin{array}{c}0.03 \\
(0.06)\end{array}$ & $\begin{array}{l}0.39^{*} \\
(0.21)\end{array}$ & $\begin{array}{l}-0.08 \\
(0.06)\end{array}$ & $\begin{array}{c}5.59 \\
(28.35)\end{array}$ \\
\hline $\begin{array}{l}\text { Post-1989 dummy*(1990-2000) } \\
\text { trend }\end{array}$ & $\begin{array}{l}0.07^{*} \\
(0.03)\end{array}$ & $\begin{array}{l}0.08^{* *} \\
(0.03)\end{array}$ & $\begin{array}{c}0.05 \\
(0.03)\end{array}$ & $\begin{array}{l}0.08^{*} \\
(0.04)\end{array}$ & $\begin{array}{c}0.06 \\
(0.08)\end{array}$ & $\begin{array}{c}-0.02 \\
(0.09)\end{array}$ & $\begin{array}{l}0.29^{* *} \\
(0.11)\end{array}$ & $\begin{array}{l}0.92^{*} \\
(0.49)\end{array}$ & $\begin{array}{c}0.06 \\
(0.03)\end{array}$ & \\
\hline State and year dummies & YES & YES & YES & YES & YES & YES & YES & YES & YES & YES \\
\hline Other controls & YES & YES & YES & YES & YES & YES & YES & YES & YES & YES \\
\hline Adjusted R-squared & 0.98 & 0.94 & 0.93 & 0.98 & 0.98 & 0.86 & 0.94 & 0.96 & 0.98 & 0.89 \\
\hline F-test 1 & $\begin{array}{c}20.25 \\
{[0]}\end{array}$ & $\begin{array}{c}6.73 \\
{[0.02]}\end{array}$ & $\begin{array}{c}4.54 \\
{[0.05]}\end{array}$ & $\begin{array}{c}31.4 \\
{[0]}\end{array}$ & $\begin{array}{c}0.01 \\
{[0.94]}\end{array}$ & $\begin{array}{c}0.04 \\
{[0.85]}\end{array}$ & $\begin{array}{c}2.69 \\
{[0.12]}\end{array}$ & $\begin{array}{c}8.15 \\
{[0.18]}\end{array}$ & $\begin{array}{c}5.06 \\
{[0.03]}\end{array}$ & $\begin{array}{c}0.09 \\
{[0.77]}\end{array}$ \\
\hline F-test 2 & $\begin{array}{c}4.65 \\
{[0.04]}\end{array}$ & $\begin{array}{c}2.13 \\
{[0.16]}\end{array}$ & $\begin{array}{c}1.87 \\
{[0.19]}\end{array}$ & $\begin{array}{c}4.47 \\
{[0.05]}\end{array}$ & $\begin{array}{c}2.05 \\
{[0.17]}\end{array}$ & $\begin{array}{c}3.96 \\
{[0.06]}\end{array}$ & $\begin{array}{c}0.38 \\
{[0.54]}\end{array}$ & $\begin{array}{c}3.48 \\
{[0.08]}\end{array}$ & $\begin{array}{c}4.01 \\
{[0.06]}\end{array}$ & \\
\hline Number observations & 579 & 579 & 579 & 579 & 577 & 579 & 579 & 561 & 573 & 365 \\
\hline
\end{tabular}

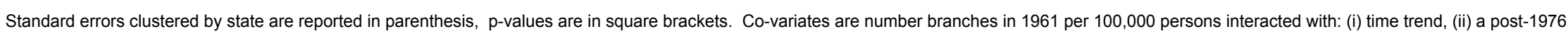

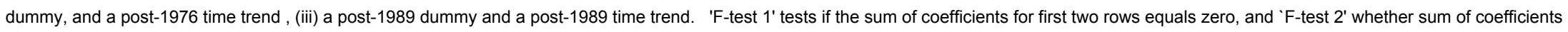

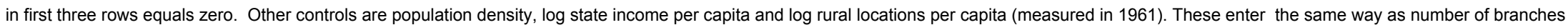

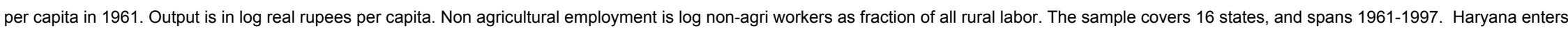
in 1965 . Sample size variations are due to missing data (see Data Appendix). ${ }^{*}$ indicates significance at $10 \%,{ }^{* *}$ at $5 \%$ and ${ }^{* * *}$ at $1 \%$. 
TABLE 6: BANK BRANCH EXPANSION, POLITICS AND POLICY: REDUCED FORM EVIDENCE

\begin{tabular}{|c|c|c|c|c|c|c|}
\hline & \multicolumn{2}{|c|}{ POLITICS } & \multicolumn{4}{|c|}{ POLICY } \\
\hline & \multirow{2}{*}{$\begin{array}{c}\text { Fraction Congress } \\
\text { legislators }\end{array}$} & \multirow{2}{*}{$\begin{array}{c}\text { Center-state } \\
\text { alignment }\end{array}$} & \multirow{2}{*}{$\begin{array}{l}\text { Land } \\
\text { reform }\end{array}$} & \multirow{2}{*}{$\begin{array}{l}\text { Public food } \\
\text { distribution }\end{array}$} & \multicolumn{2}{|c|}{ Share of state spending on } \\
\hline & & & & & Health and education & Other development \\
\hline & $(1)$ & $(2)$ & (3) & $(4)$ & $(5)$ & $(6)$ \\
\hline Number of bank branches in 1961 & -0.01 & $-0.04^{*}$ & 0.005 & 35.62 & -0.0004 & 0.002 \\
\hline per capita *(1961-2000) trend & $(0.01)$ & $(0.02)$ & $(0.05)$ & $(71.37)$ & $(0.0013)$ & $(0.001)$ \\
\hline Number of bank branches in 1961 & 0.005 & 0.04 & -0.09 & 45.54 & -0.001 & -0.0001 \\
\hline per capita*(1977-2000) trend & $(0.02)$ & $(0.03)$ & $(0.04)$ & $(77.42)$ & $(0.0016)$ & $(0.0030)$ \\
\hline Number of bank branches in 1961 & -0.004 & 0.08 & $0.08^{*}$ & -20.04 & 0.0002 & -0.001 \\
\hline per capita*(1990-2000) trend & $(0.017)$ & $(0.04)$ & $(0.04)$ & $(217.92)$ & $(0.0019)$ & $(0.005)$ \\
\hline Post-1976 dummy* (1977-2000) & 0.14 & 0.3 & $-0.85^{\star *}$ & -530.33 & -0.01 & -0.002 \\
\hline trend & $(0.24)$ & $(0.27)$ & $(0.29)$ & $(1029.74)$ & $(0.01)$ & $(0.01)$ \\
\hline Post-1989 dummy*(1990-2000) & $0.23^{* *}$ & -0.10 & $-0.54^{* * *}$ & 464.14 & -0.004 & 0.01 \\
\hline trend & $(0.10)$ & $(0.34)$ & $(0.19)$ & $(292.69)$ & $(0.01)$ & $(0.01)$ \\
\hline State and year dummies & YES & YES & YES & YES & YES & YES \\
\hline Other controls & YES & YES & YES & YES & YES & YES \\
\hline Adjusted R-squared & 0.56 & 0.59 & 0.73 & 0.79 & 0.72 & 0.7 \\
\hline \multirow[t]{2}{*}{ F-test 1} & 0.16 & 0.01 & 3.82 & 0.41 & 5.32 & 1.61 \\
\hline & [0.69] & [0.91] & {$[0.06]$} & [0.53] & [0.03] & {$[0.22]$} \\
\hline \multirow[t]{2}{*}{ F-test 2} & 0.33 & 2.95 & 0.01 & 0.16 & 1.34 & 0.16 \\
\hline & {$[0.57]$} & {$[0.10]$} & {$[0.91]$} & [0.69] & {$[0.26]$} & [0.69] \\
\hline Number observations & 634 & 539 & 636 & 522 & 613 & 613 \\
\hline
\end{tabular}

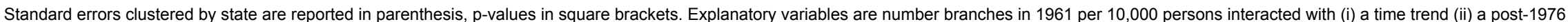

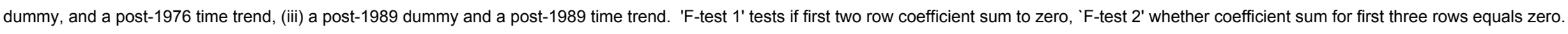

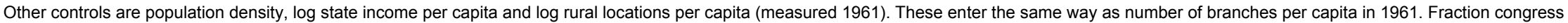

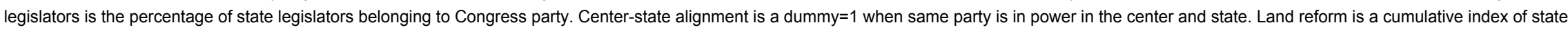

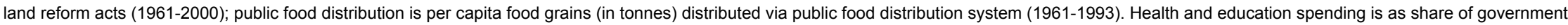

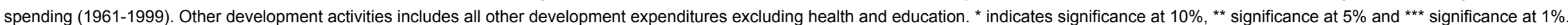


TABLE 7: BANK BRANCH EXPANSION AND POVERTY -- INSTRUMENTAL VARIABLES EVIDENCE

\begin{tabular}{|c|c|c|c|c|c|c|c|c|c|c|}
\hline & & \multicolumn{7}{|c|}{ Head count ratio } & \multicolumn{2}{|c|}{ Wage } \\
\hline & & \multicolumn{2}{|c|}{ Rural } & \multirow{2}{*}{$\begin{array}{c}\text { Urban } \\
\text { IV }\end{array}$} & \multirow{2}{*}{$\begin{array}{c}\text { Aggregate } \\
\text { IV }\end{array}$} & \multicolumn{3}{|c|}{ Rural } & \multirow{2}{*}{$\frac{\text { Agricultural }}{\text { IV }}$} & \multirow{2}{*}{$\frac{\text { Factory }}{\text { IV }}$} \\
\hline & & & IV & & & IV & IV & IV & & \\
\hline & & & & & & $1961-89$ & $1977-2000$ & survey years & & \\
\hline & $(1)$ & $(2)$ & $(3)$ & $(4)$ & $(5)$ & $(6)$ & $(7)$ & $(8)$ & $(9)$ & $(10)$ \\
\hline $\begin{array}{l}\text { Number branches opened in rural } \\
\text { unbanked locations per capita }\end{array}$ & $\begin{array}{l}2.09^{* *} \\
(0.79)\end{array}$ & $\begin{array}{c}1.15 \\
(1.02)\end{array}$ & $\begin{array}{l}-4.74^{\star *} \\
(1.79)\end{array}$ & $\begin{array}{l}-0.65 \\
(1.06)\end{array}$ & $\begin{array}{l}-4.10^{* *} \\
(1.46)\end{array}$ & $\begin{array}{l}-4.70^{\star *} \\
(1.82)\end{array}$ & $\begin{array}{l}-6.83^{* *} \\
(2.80)\end{array}$ & $\begin{array}{l}-4.20^{*} \\
(2.26)\end{array}$ & $\begin{array}{l}0.07^{*} \\
(0.04)\end{array}$ & $\begin{array}{c}0.04 \\
(0.08)\end{array}$ \\
\hline IMPLIED ELASTICITY & & & -0.36 & & -0.32 & & & & 0.25 & \\
\hline $\begin{array}{l}\text { Number of bank branches in } 1961 \\
\text { per capita * } 1961-2000 \text { trend }\end{array}$ & & $\begin{array}{c}-0.43^{* * *} \\
(0.16)\end{array}$ & $\begin{array}{l}-0.47 \\
(0.26)\end{array}$ & $\begin{array}{l}-0.26^{*} \\
(0.13)\end{array}$ & $\begin{array}{l}-0.46^{*} \\
(0.22)\end{array}$ & $\begin{array}{l}-0.43 \\
(0.26)\end{array}$ & $\begin{array}{l}-0.79^{*} \\
(0.44)\end{array}$ & $\begin{array}{l}-0.45 \\
(0.28)\end{array}$ & $\begin{array}{l}-0.006 \\
(0.003)\end{array}$ & $\begin{array}{l}0.005 \\
(0.01)\end{array}$ \\
\hline $\begin{array}{l}\text { Post-1976 dummy* (1977-2000) } \\
\text { trend }\end{array}$ & & $\begin{array}{l}-0.31 \\
(1.22)\end{array}$ & $\begin{array}{l}-1.42 \\
(2.29)\end{array}$ & $\begin{array}{l}-2.06 \\
(1.65)\end{array}$ & $\begin{array}{l}-1.39 \\
(2.03)\end{array}$ & $\begin{array}{l}-2.13 \\
(2.58)\end{array}$ & & $\begin{array}{l}-1.31 \\
(3.32)\end{array}$ & $\begin{array}{l}0.04 \\
(0.05)\end{array}$ & $\begin{array}{c}0.03 \\
(0.06)\end{array}$ \\
\hline State and year dummies & YES & YES & YES & YES & YES & YES & YES & YES & YES & YES \\
\hline Other controls & NO & YES & YES & YES & YES & YES & YES & YES & YES & YES \\
\hline $\begin{array}{l}\text { Overidentification test } p \text { - } \\
\text { value }\end{array}$ & & & 0.99 & 0.98 & 0.99 & & & 1 & 0.99 & 0.99 \\
\hline R-squared & 0.82 & 0.85 & 0.78 & 0.92 & 0.81 & 0.8 & 0.8 & 0.77 & 0.98 & 0.7 \\
\hline Number observations & 627 & 627 & 627 & 627 & 627 & 460 & 375 & 375 & 545 & 553 \\
\hline
\end{tabular}

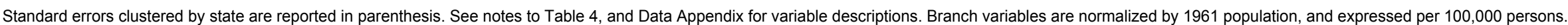

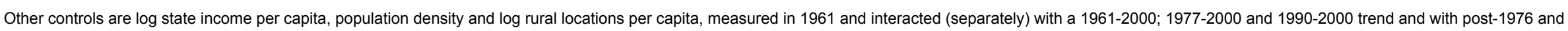

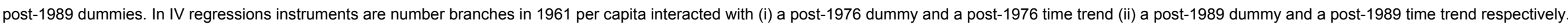
Table 3, column (1) reports corresponding first stage regression. The p-value for an overidentification test due to Sargan [1958] is reported -- number of observations times R-2 from the regression of stage two residuals on the instruments is distributed chi-squared $(T+1)$ where $T$ is the number of instruments. ${ }^{*}$ indicates significance at $10 \%$, ${ }^{* *}$ significance at $5 \%$ and ${ }^{* * *}$ significance at $1 \%$ 
TABLE 8: BANK BRANCH EXPANSION AND OUTPUT -- INSTRUMENTAL VARIABLES EVIDENCE

\begin{tabular}{|c|c|c|c|c|c|c|c|c|c|c|}
\hline & \multirow{3}{*}{$\begin{array}{c}\text { State } \\
\text { output } \\
\text { Total } \\
\end{array}$} & \multirow{2}{*}{\multicolumn{2}{|c|}{ Primary sector output }} & \multirow{3}{*}{$\begin{array}{c}\text { Non-prima } \\
\text { ry output } \\
\text { Total }\end{array}$} & \multicolumn{4}{|c|}{ Secondary sector output } & \multirow{3}{*}{$\begin{array}{c}\text { Tertiary } \\
\text { total } \\
\text { output }\end{array}$} & \multirow{3}{*}{$\begin{array}{c}\text { Employment } \\
\text { Non-agri } \\
\text { labor }\end{array}$} \\
\hline & & & & & \multirow{3}{*}{$\begin{array}{c}\text { Construction } \\
(5)\end{array}$} & \multicolumn{2}{|c|}{ Manufacturing } & \multirow{3}{*}{$\begin{array}{c}\text { Electricity, } \\
\text { water, gas } \\
(8)\end{array}$} & & \\
\hline & & Total & Agriculture & & & Registered & Unregistered & & & \\
\hline & $(1)$ & $(2)$ & (3) & $(4)$ & & $(6)$ & $(7)$ & & $(9)$ & $(10)$ \\
\hline Number bank branches in rural & $0.08^{* * *}$ & 0.04 & 0.01 & $0.15^{* * *}$ & -0.09 & 0.05 & $0.29^{*}$ & $0.30^{* *}$ & $0.17^{* * *}$ & 0.3 \\
\hline unbanked locations per capita & $(0.02)$ & $(0.03)$ & $(0.03)$ & $(0.03)$ & $(0.19)$ & $(0.07)$ & $(0.15)$ & $(0.13)$ & $(0.05)$ & $(0.22)$ \\
\hline IMPLIED ELASTICITY & 0.29 & & & 0.55 & & & 1.07 & 1.11 & 0.62 & \\
\hline Number bank branches in 1961 & 0.004 & $-0.01^{*}$ & $-0.01^{* *}$ & $0.01^{* *}$ & -0.01 & 0.01 & $0.02^{*}$ & -0.02 & $0.02^{*}$ & $0.06^{* * *}$ \\
\hline per capita * $(1961-2000)$ trend & $(0.003)$ & $(0.00)$ & $(0.00)$ & $(0.01)$ & $(0.02)$ & $(0.01)$ & $(0.01)$ & $(0.02)$ & $(0.01)$ & $(0.01)$ \\
\hline Post-1976 dummy* (1977-2000) & 0.004 & $0.09^{* *}$ & $0.12^{* * *}$ & -0.1 & 0.06 & 0.06 & -0.1 & $0.38^{*}$ & $-0.15^{\star}$ & -0.03 \\
\hline trend & $(0.04)$ & $(0.04)$ & $(0.03)$ & $(0.06)$ & $(0.17)$ & $(0.06)$ & $(0.14)$ & $(0.19)$ & $(0.08)$ & $(0.22)$ \\
\hline Post-1989 dummy*(1990-2000) & $0.15^{\star * *}$ & $0.16^{\star * *}$ & $0.13^{* *}$ & $0.14^{* * *}$ & 0.18 & $0.16^{*}$ & $0.33^{* *}$ & $0.70^{*}$ & $0.08^{* *}$ & \\
\hline trend & $(0.03)$ & $(0.05)$ & $(0.04)$ & $(0.03)$ & $(0.11)$ & $(0.08)$ & $(0.14)$ & $(0.35)$ & $(0.03)$ & \\
\hline State and year dummies & YES & YES & YES & YES & YES & YES & YES & YES & YES & YES \\
\hline Other controls & YES & YES & YES & YES & YES & YES & YES & YES & YES & YES \\
\hline Overidentification test $p$-value & 0.98 & 0.97 & 0.97 & 0.99 & 0.91 & 0.97 & 0.99 & 0.98 & 0.99 & \\
\hline Adjusted R-squared & 0.96 & 0.93 & 0.93 & 0.96 & 0.98 & 0.94 & 0.82 & 0.7 & 0.96 & 0.88 \\
\hline Number observations & 579 & 579 & 579 & 579 & 577 & 579 & 579 & 561 & 573 & 365 \\
\hline
\end{tabular}

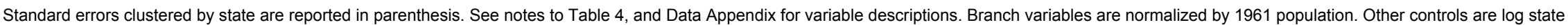

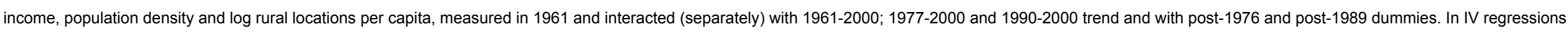

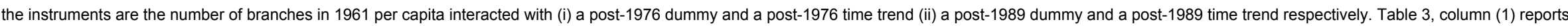

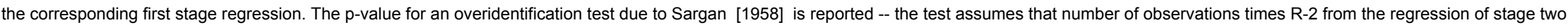
residuals on the instruments is distributed chi-squared $(T+1)$ where $T$ is the number of instruments. * indicates significance at $10 \%$, ${ }^{* *}$ significance at $5 \%$ and ${ }^{* * *}$ significance at $1 \%$ 
TABLE 9: THE IMPACT OF RURAL CREDIT AND SAVINGS ON POVERTY AND OUTPUT -- INSTRUMENTAL VARIABLES EVIDENCE

\begin{tabular}{|c|c|c|c|c|c|c|c|c|c|c|}
\hline & \multicolumn{4}{|c|}{ Head count ratio } & \multicolumn{6}{|c|}{ Output } \\
\hline & \multicolumn{2}{|c|}{ Rural } & \multicolumn{2}{|c|}{ Urban } & \multicolumn{2}{|c|}{ Total } & \multicolumn{2}{|c|}{ Primary sector } & \multicolumn{2}{|c|}{ Non-primary sector } \\
\hline & $(1)$ & (2) & $(3)$ & (4) & $(5)$ & (6) & $(7)$ & $(8)$ & $(9)$ & $(10)$ \\
\hline $\begin{array}{l}\text { Share of bank credit disbursed } \\
\text { by rural branches }\end{array}$ & $\begin{array}{l}-1.49^{* *} \\
(0.67)\end{array}$ & & $\begin{array}{l}-0.64 \\
(0.45)\end{array}$ & & $\begin{array}{l}0.02^{*} \\
(0.01)\end{array}$ & & $\begin{array}{c}0.01 \\
(0.01)\end{array}$ & & $\begin{array}{l}0.03^{* *} \\
(0.02)\end{array}$ & \\
\hline $\begin{array}{l}\text { Share of bank savings held by } \\
\text { rural branches }\end{array}$ & & $\begin{array}{l}-2.27^{* *} \\
(0.80)\end{array}$ & & $\begin{array}{l}-1.09 \\
(0.69)\end{array}$ & & $\begin{array}{l}0.02^{*} \\
(0.01)\end{array}$ & & $\begin{array}{l}0.01 \\
(0.01)\end{array}$ & & $\begin{array}{l}0.03^{* * *} \\
(0.01)\end{array}$ \\
\hline $\begin{array}{l}\text { Number bank branches in } 1961 \\
\text { per capita * (1961-2000) trend }\end{array}$ & $\begin{array}{l}-0.98^{*} \\
(0.48)\end{array}$ & $\begin{array}{l}-1.56^{\star *} \\
(0.59)\end{array}$ & $\begin{array}{l}-0.69^{* *} \\
(0.24)\end{array}$ & $\begin{array}{c}-1.00^{* *} \\
(0.36)\end{array}$ & $\begin{array}{c}0.01 \\
(0.01)\end{array}$ & $\begin{array}{l}0.02^{* *} \\
(0.01)\end{array}$ & $\begin{array}{r}-0.001 \\
(0.01)\end{array}$ & $\begin{array}{l}-0.001 \\
(0.01)\end{array}$ & $\begin{array}{l}0.01^{* *} \\
(0.01)\end{array}$ & $\begin{array}{l}0.02^{* *} \\
(0.01)\end{array}$ \\
\hline $\begin{array}{l}\text { Post-1976 dummy* (1977-2000) } \\
\text { trend }\end{array}$ & $\begin{array}{l}-3.00^{*} \\
(1.62)\end{array}$ & $\begin{array}{l}-1.83 \\
(2.29)\end{array}$ & $\begin{array}{l}-1.64 \\
(1.96)\end{array}$ & $\begin{array}{l}-1.13 \\
(2.55)\end{array}$ & $\begin{array}{c}0.05 \\
(0.05)\end{array}$ & $\begin{array}{c}0.04 \\
(0.05)\end{array}$ & $\begin{array}{l}0.11^{\text {** }} \\
(0.05)\end{array}$ & $\begin{array}{l}0.11^{* *} \\
(0.05)\end{array}$ & $\begin{array}{l}-0.02 \\
(0.07)\end{array}$ & $\begin{array}{l}-0.03 \\
(0.06)\end{array}$ \\
\hline State and year dummies & YES & YES & YES & YES & YES & YES & YES & YES & YES & YES \\
\hline Other controls & YES & YES & YES & YES & YES & YES & YES & YES & YES & YES \\
\hline Overidentification test $p$-value & 0.99 & 0.99 & 0.99 & 0.99 & 0.98 & 0.95 & 0.99 & 0.93 & 0.99 & 0.99 \\
\hline Adjusted R-squared & 0.72 & 0.66 & 0.91 & 0.89 & 0.97 & 0.94 & 0.98 & 0.96 & 0.99 & 0.97 \\
\hline Number observations & 503 & 503 & 503 & 503 & 463 & 463 & 463 & 463 & 463 & 463 \\
\hline
\end{tabular}

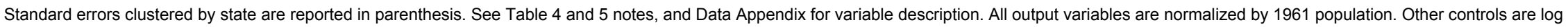

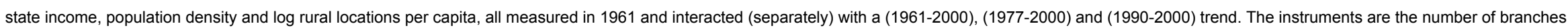

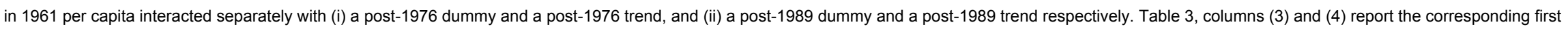

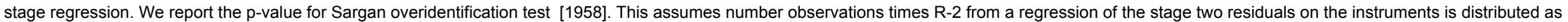
chi-squared $(T+1)$ where $T$ is the number of instruments. ${ }^{*}$ indicates significance at $10 \%$, ${ }^{* *}$ significance at $5 \%$ and ${ }^{* * *}$ significance at $1 \%$. 
TABLE 10: BANK BRANCH EXPANSION AND POVERTY REDUCTION -- IV ESTIMATES WITH TIME VARYING CONTROLS

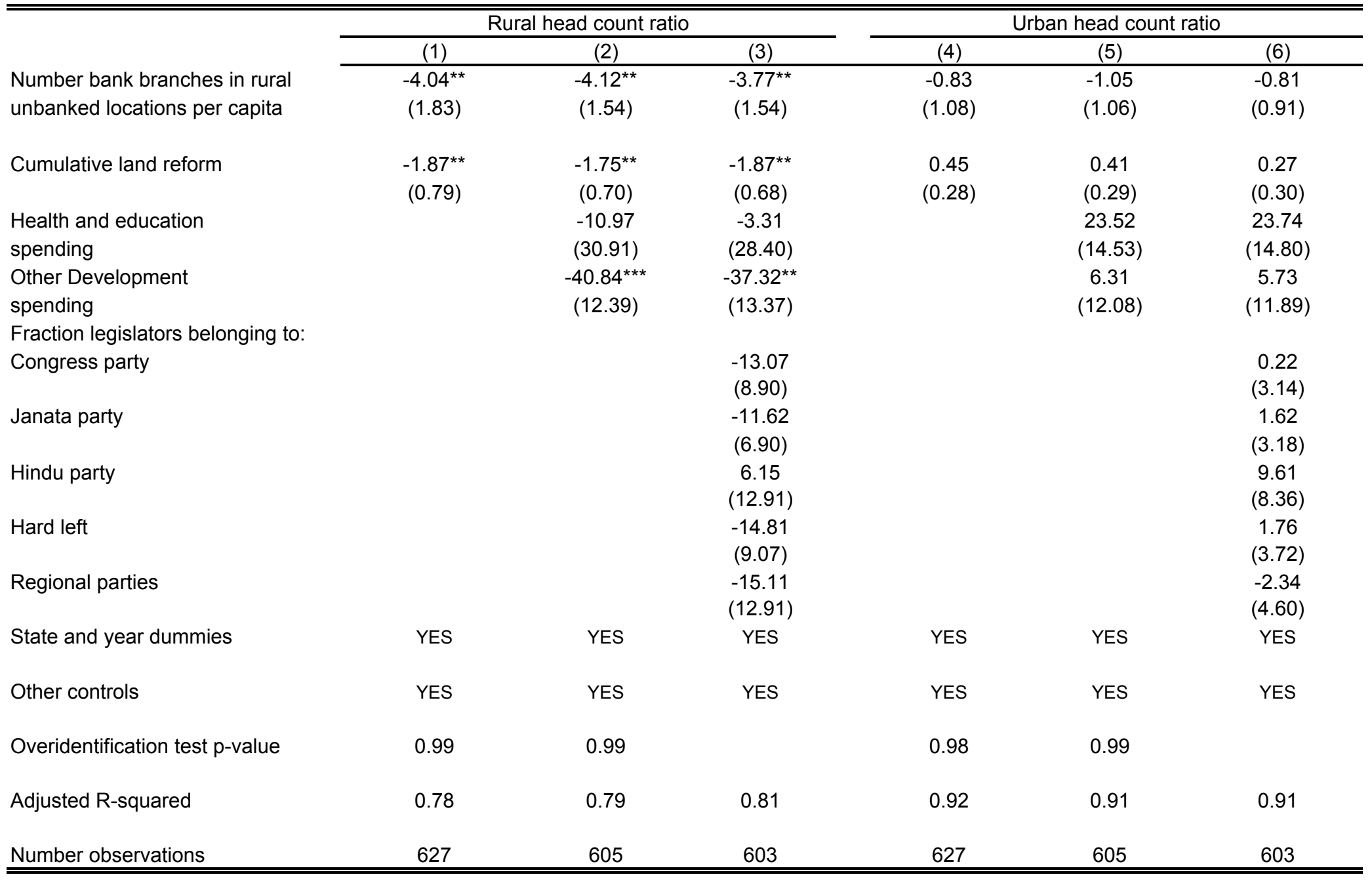

Standard errors clustered by state are reported in parenthesis. Table 4 notes, and Data Appendix provide variable description. Branch variables are normalized by 1961 population. Other controls are log state income, population density and log rural locations per capita, measured in 1961 and interacted (separately) with a (1961-2000), (1977-2000) and (1990-2000) trend. Instruments are number branches in 1961 per capita interacted with (i) a post-1976 dummy and a post-1976 time trend (ii) a post-1989 dummy and a post-1989 trend respectively. ${ }^{*}$ indicates significance at $10 \%$, ${ }^{* *}$ significance at $5 \%$ and ${ }^{* * *}$ significance at $1 \%$. 
TABLE 11: LAND OWNERSHIP AND BORROWING BY RURAL HOUSEHOLDS IN INDIA, 1983-1993

\begin{tabular}{lccccc}
\hline \hline & \multicolumn{5}{c}{ Land ownership in acres } \\
\cline { 2 - 6 } & No land & $0-0.1$ & $0.1-0.5$ & $0.5-2.5$ & more than 2.5 \\
\cline { 2 - 6 } & 0.09 & 0.08 & 0.09 & 0.1 & 0.12 \\
$\begin{array}{l}\text { Proportion of households with a bank } \\
\text { loan }\end{array}$ & 0.14 & 0.15 & 0.18 & 0.19 & 0.24 \\
$\begin{array}{l}\text { Proportion of households with a } \\
\text { moneylender loan }\end{array}$ & 9,619 & 25,350 & 16,581 & 13,824 & 2,764 \\
Number of observations & & & & & \\
\hline \hline
\end{tabular}

The proportion of households with a bank loan refer to the fraction of households in a given land category with atleast one outstanding bank loan. Moneylender borrowing is similarly defined. The means are computed for the sample of rural labor households in the NSS quinquennial employment and unemployment surveys for the years 1983, 1987 and 1993. 


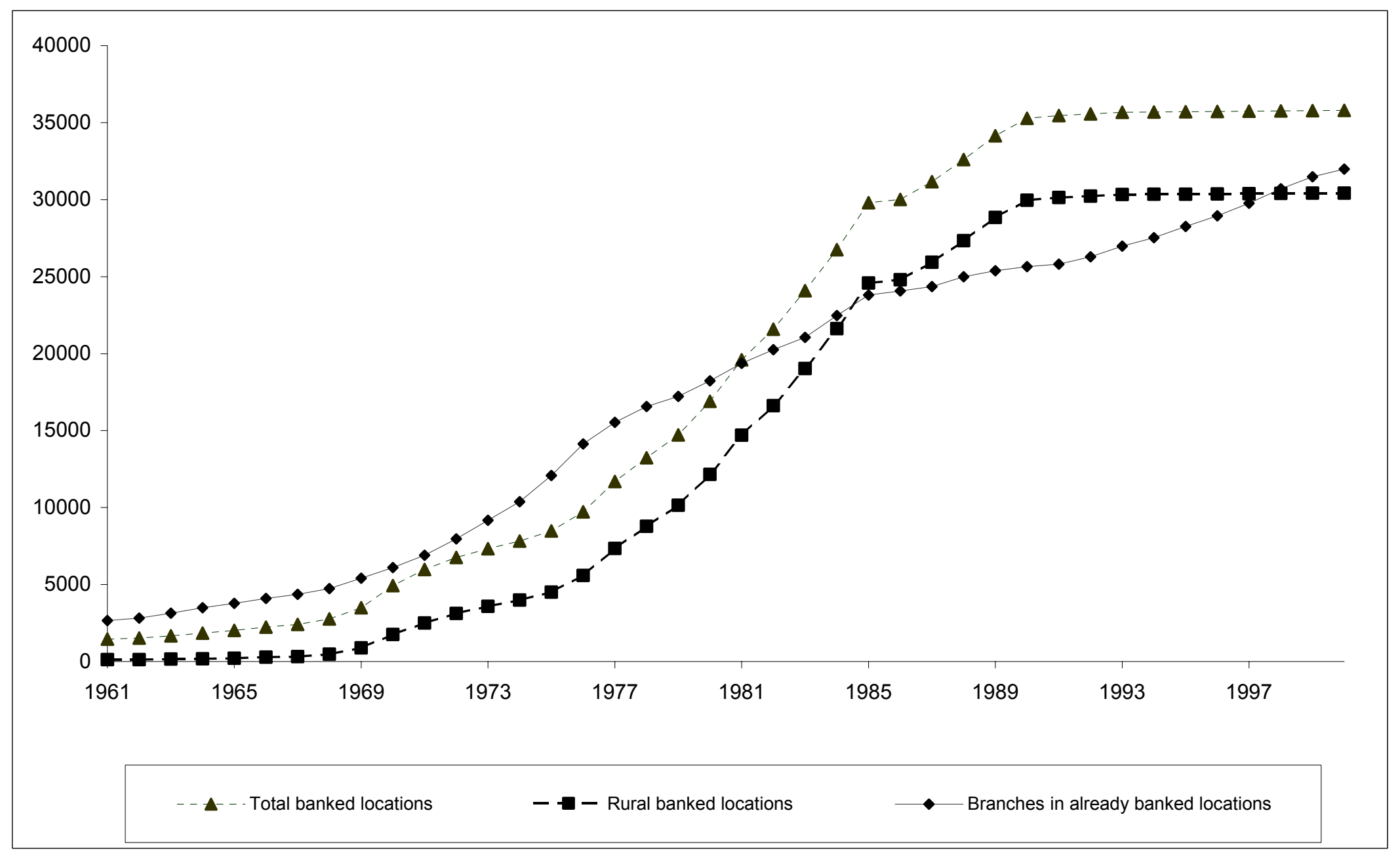

FIGURE 1: GROWTH OF BANK BRANCHES IN INDIA

Notes: All variables refer to the cumulative number of branches (of that type). These variables are constructed using information from the Reserve

Bank of India Basic Statistical Returns, as provided in the 'Directory of Commercial Bank Offices in India (Volume 1)', The Data Appendix provides a full description of these data. 


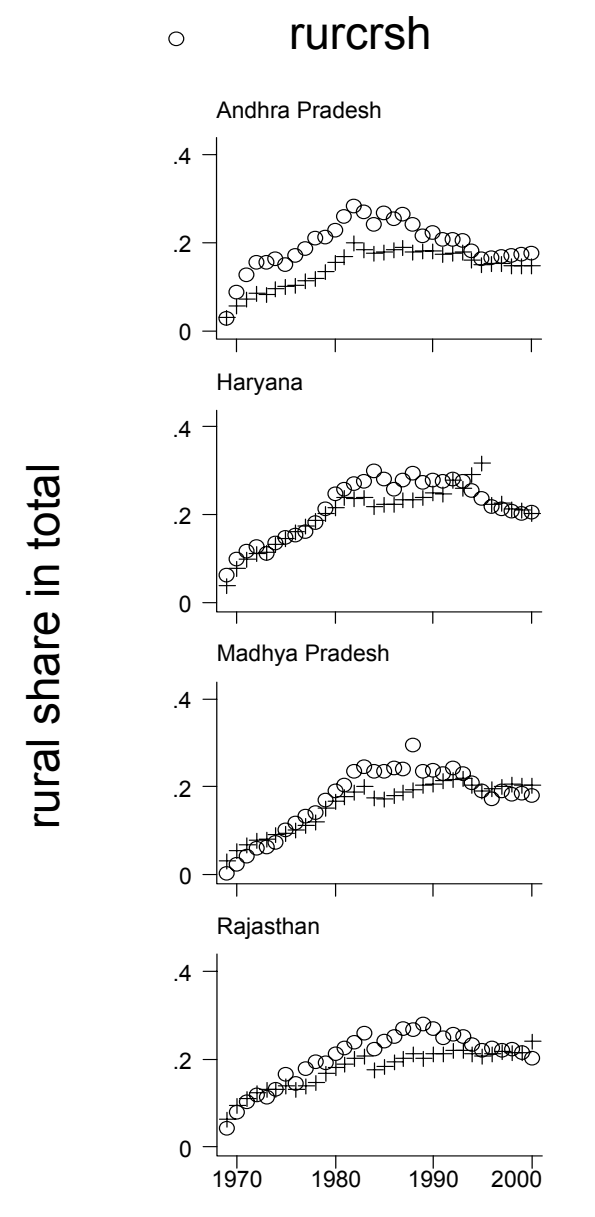

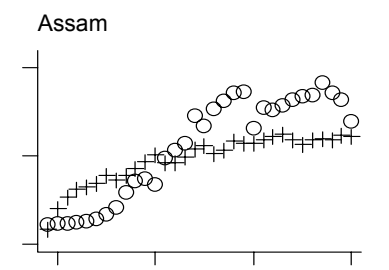

Jammu \& Kashmir
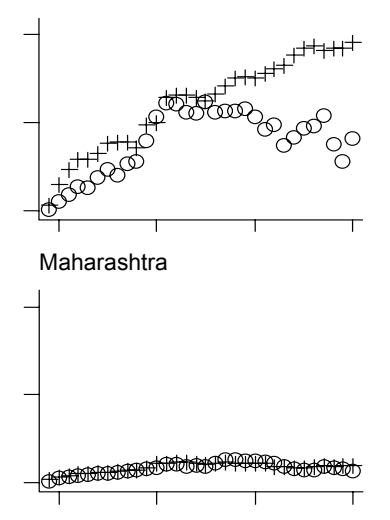

Tamil Nadu

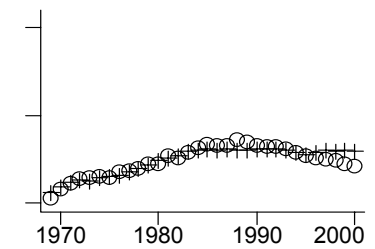

$+\quad$ rursavsh

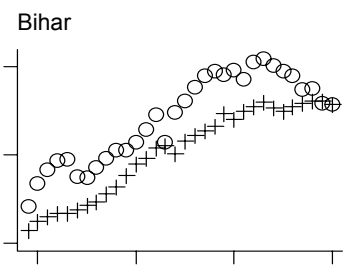

Karnataka

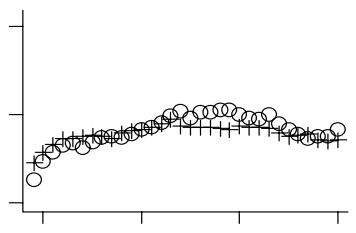

Orissa

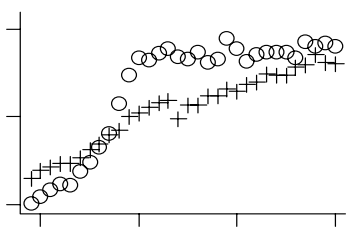

Uttar Pradesh

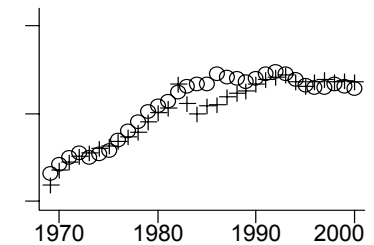

Gujarat

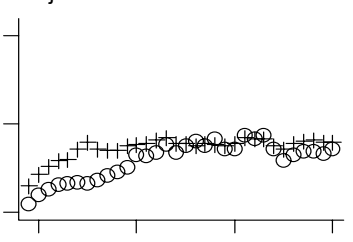

Kerala

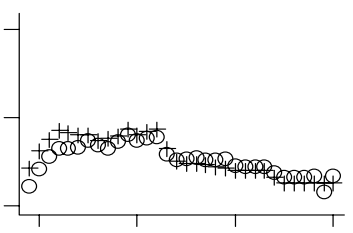

Punjab

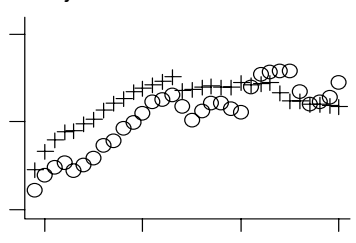

West Bengal

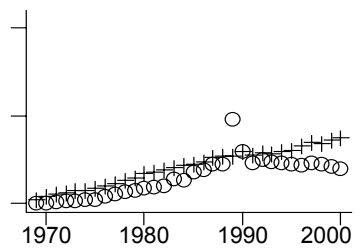

\section{Figure 2: Rural credit and saving in Indian states}

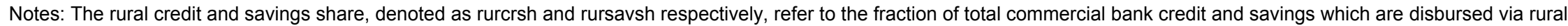
bank branches. The Data Appendix provides information on the construction of these variables. 
○

\section{rural headcount ratio}

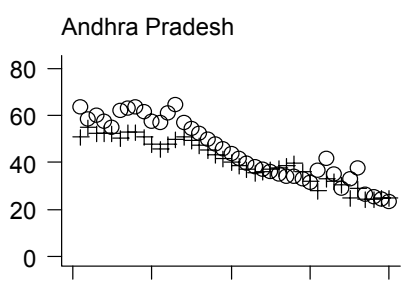

Haryana

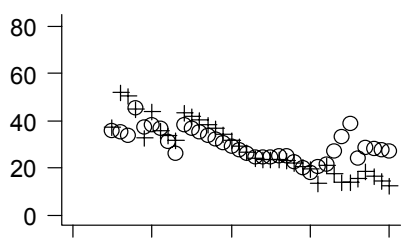

Madhya Pradesh

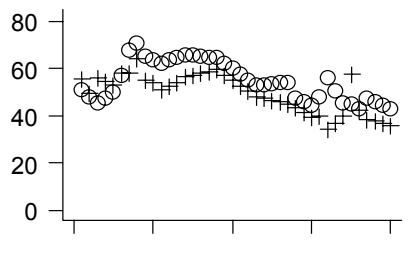

\section{Rajasthan}

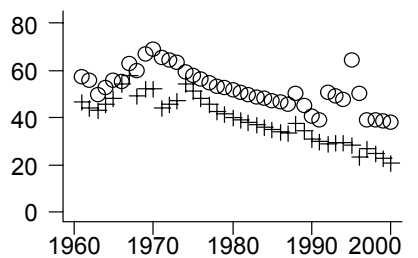

Assam

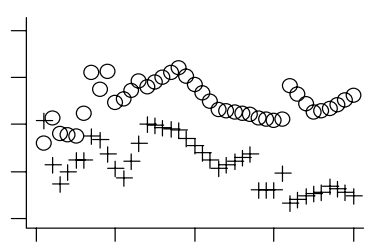

Jammu \& Kashmir

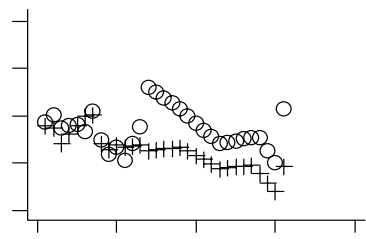

Maharashtra

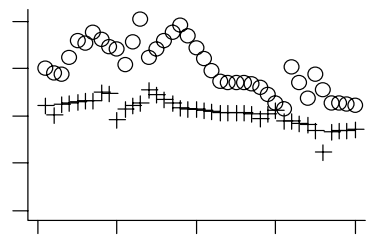

Tamil Nadu

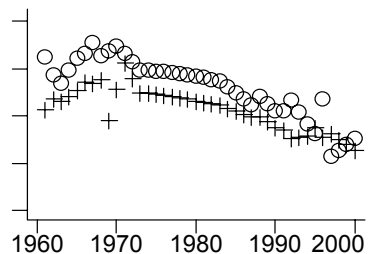

$+\quad$ urban headcount ratio

Bihar

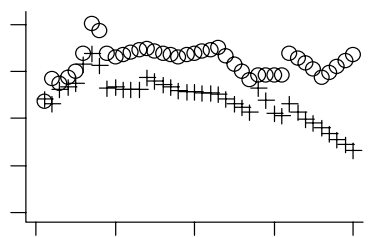

Karnataka

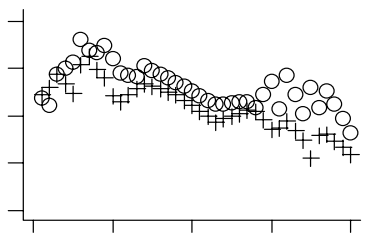

Orissa

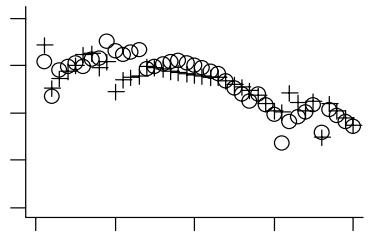

Uttar Pradesh

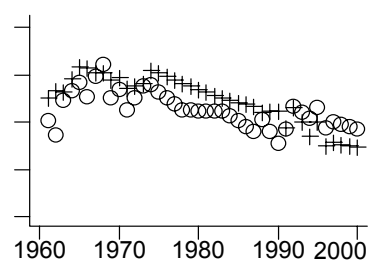

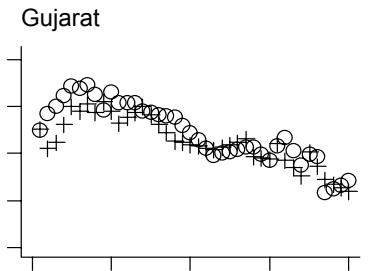

Kerala

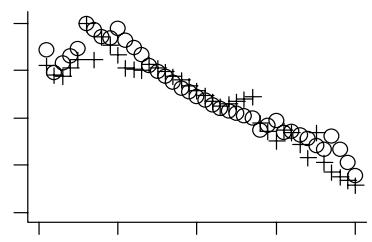

Punjab

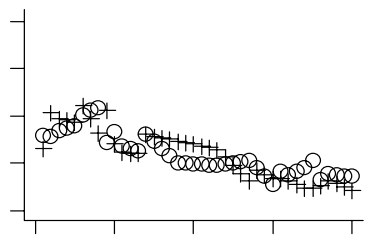

West Bengal

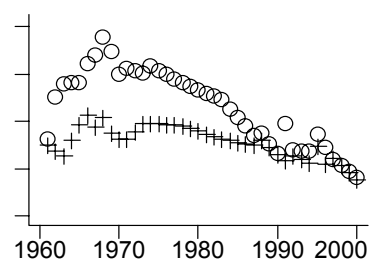

\section{Figure 3: Poverty across Indian States}

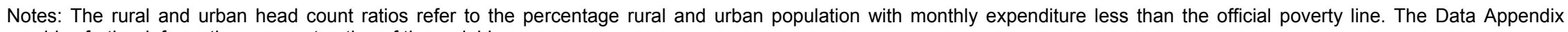
provides further information on construction of the variables. 
- Primary sector output
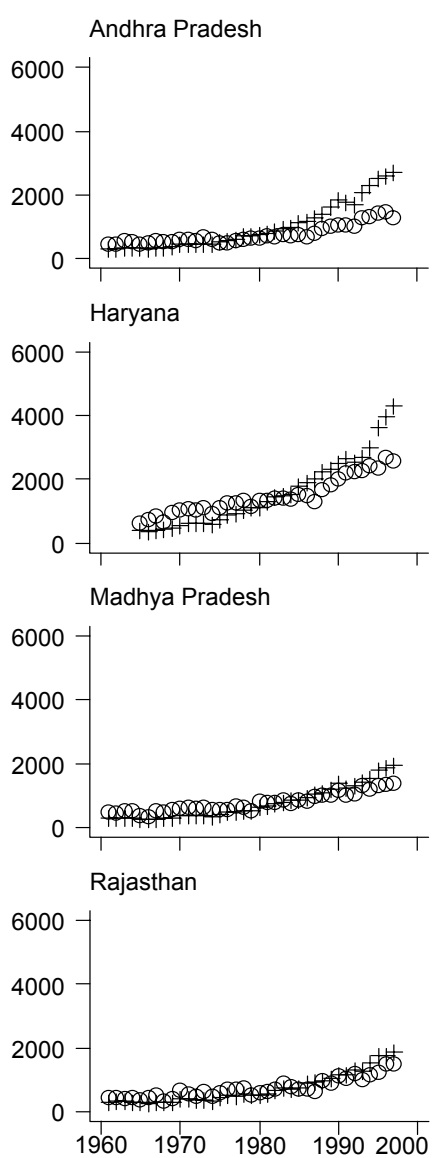

Assam

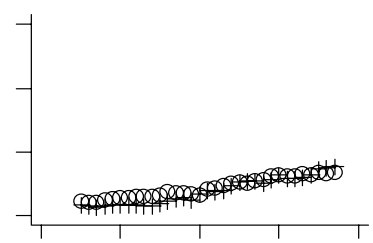

Jammu \& Kashmir

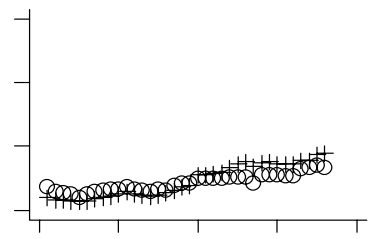

Maharashtra

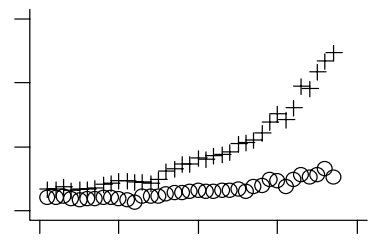

Tamil Nadu

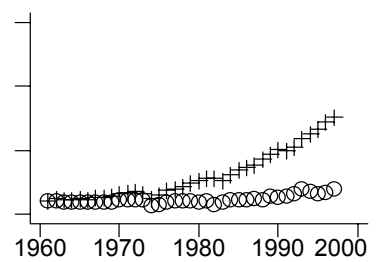

+ State non-primary output

Bihar

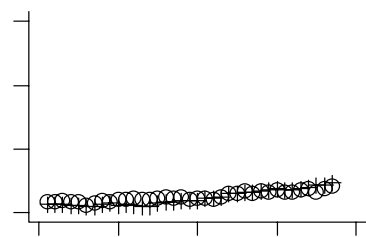

Karnataka

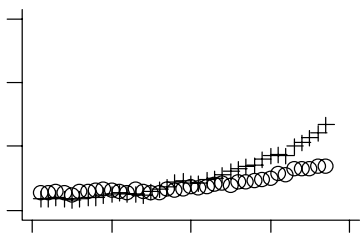

Orissa

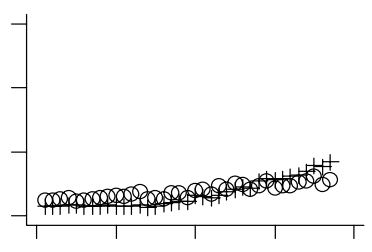

Uttar Pradesh

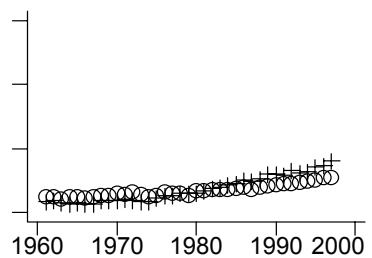

Gujarat
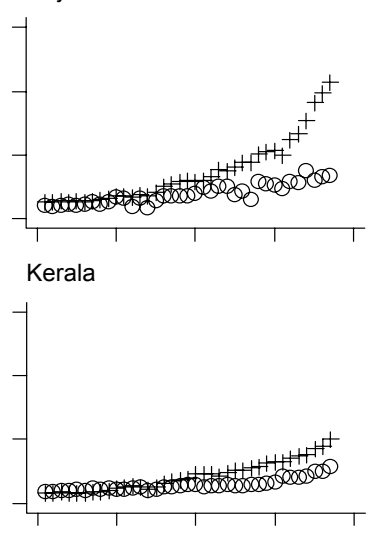

Punjab

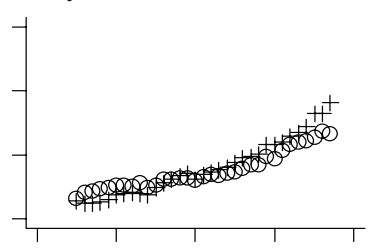

West Bengal

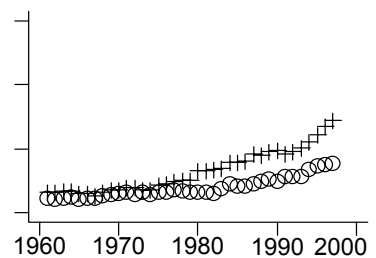

\section{Figure 4: Output across Indian states}

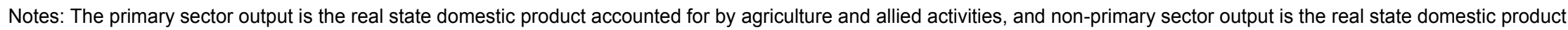
accounted for by the secondary and tertiary sectors. Both variables are normalized by 1961 population. The Data Appendix provides information on variable construction. 


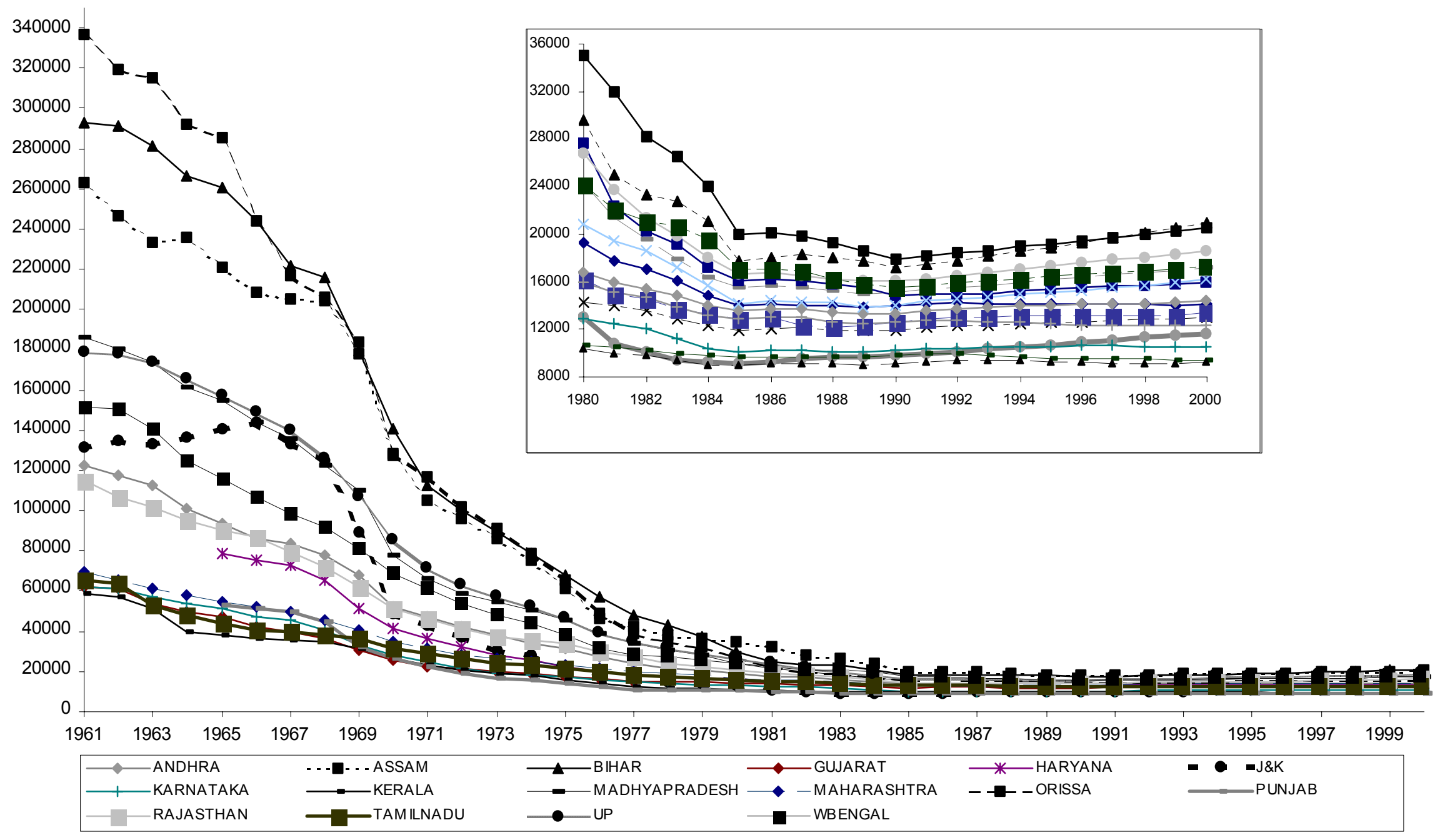

FIGURE 5: POPULATION PER BANK BRANCH ACROSS 16 INDIAN STATES

Notes: This variable is the ratio of the state's current population divided by the total number of bank branches in the state. The Data Appendix describes the data sources. 


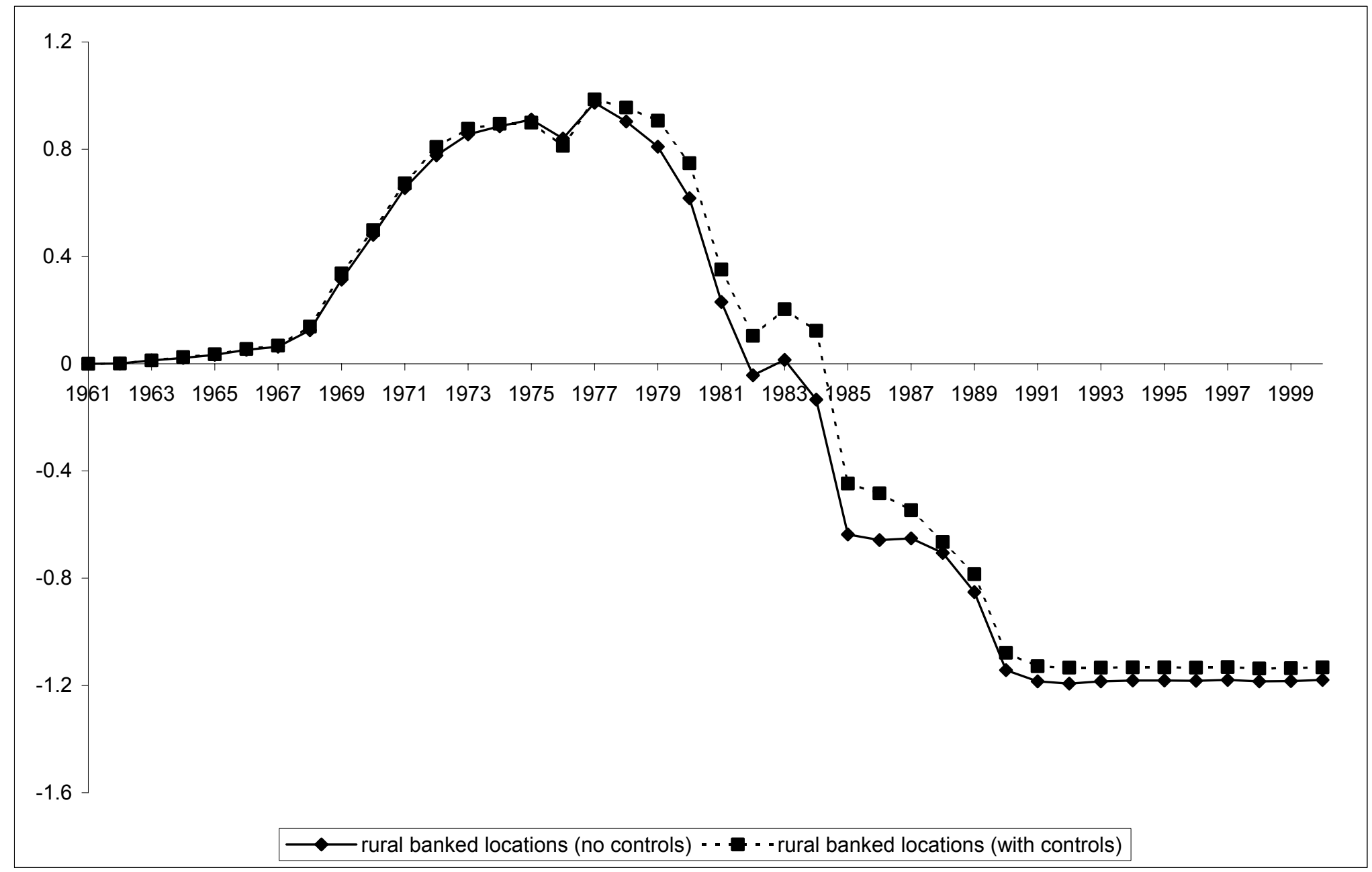

FIGURE 6: INITIAL FINANCIAL DEVELOPMENT AND BRANCH EXPANSION INTO RURAL UNBANKED LOCATIONS

Notes: This figure graphs the coefficients for two regressions. The series "Rural banked locations (no controls) "graphs the set of "number of banked locations in 1961" Xyear interaction terms from the regression given in Equation (1), and the series "Rural banked locations (with controls)" graphs the corresponding set of interaction terms from the regression in Equation (2) which includes population, income and location controls, 


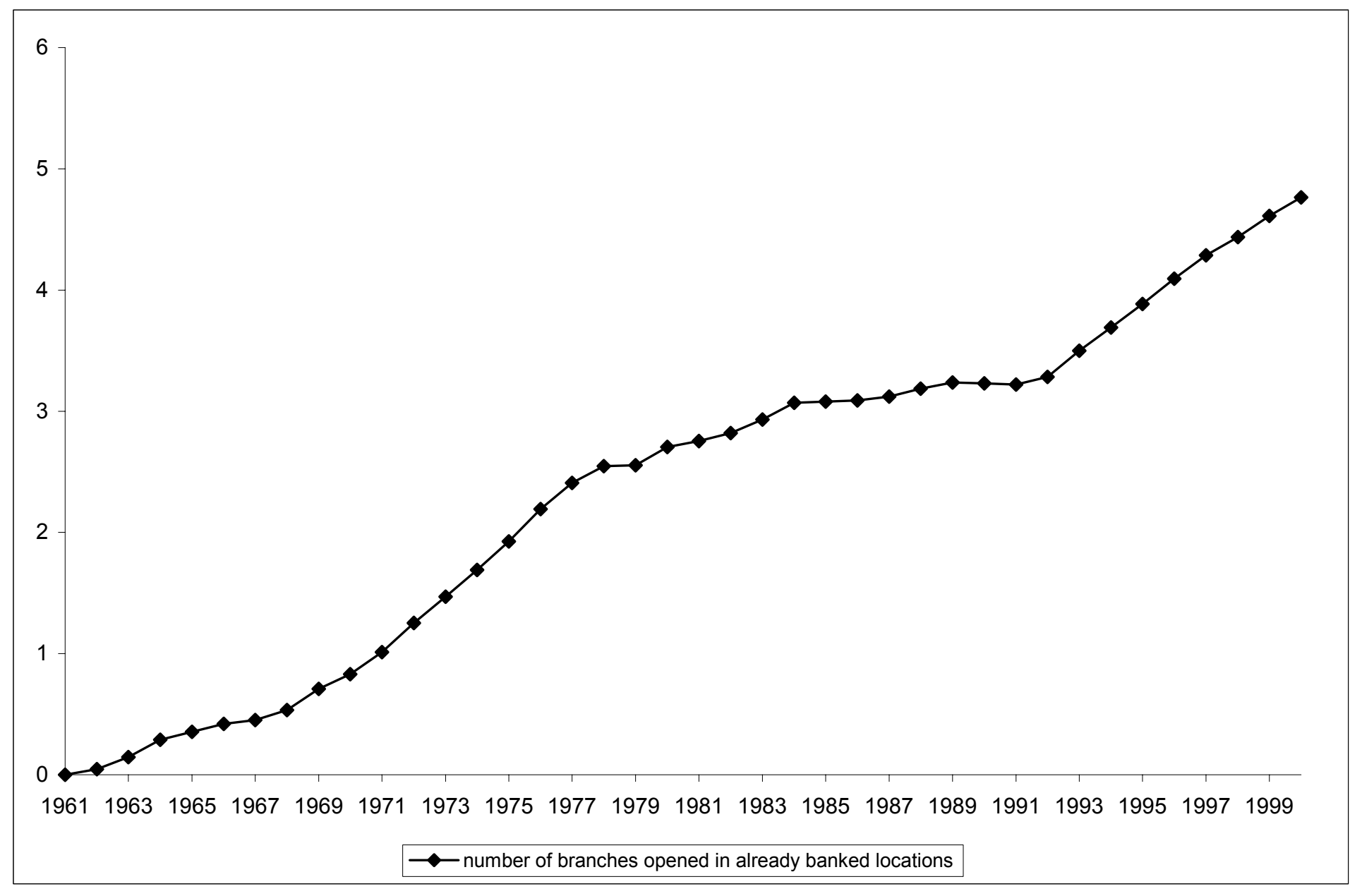

FIGURE 7: INITIAL FINANCIAL DEVELOPMENT AND BRANCH EXPANSION IN ALREADY BANKED LOCATIONS

Notes: This figure graphs the set of "Number of banked locations in $1961 \times$ Year" Interaction terms from a regression in which the dependent variable is the number of branches opened in already banked locations. The regression includes population, income and location controls, 


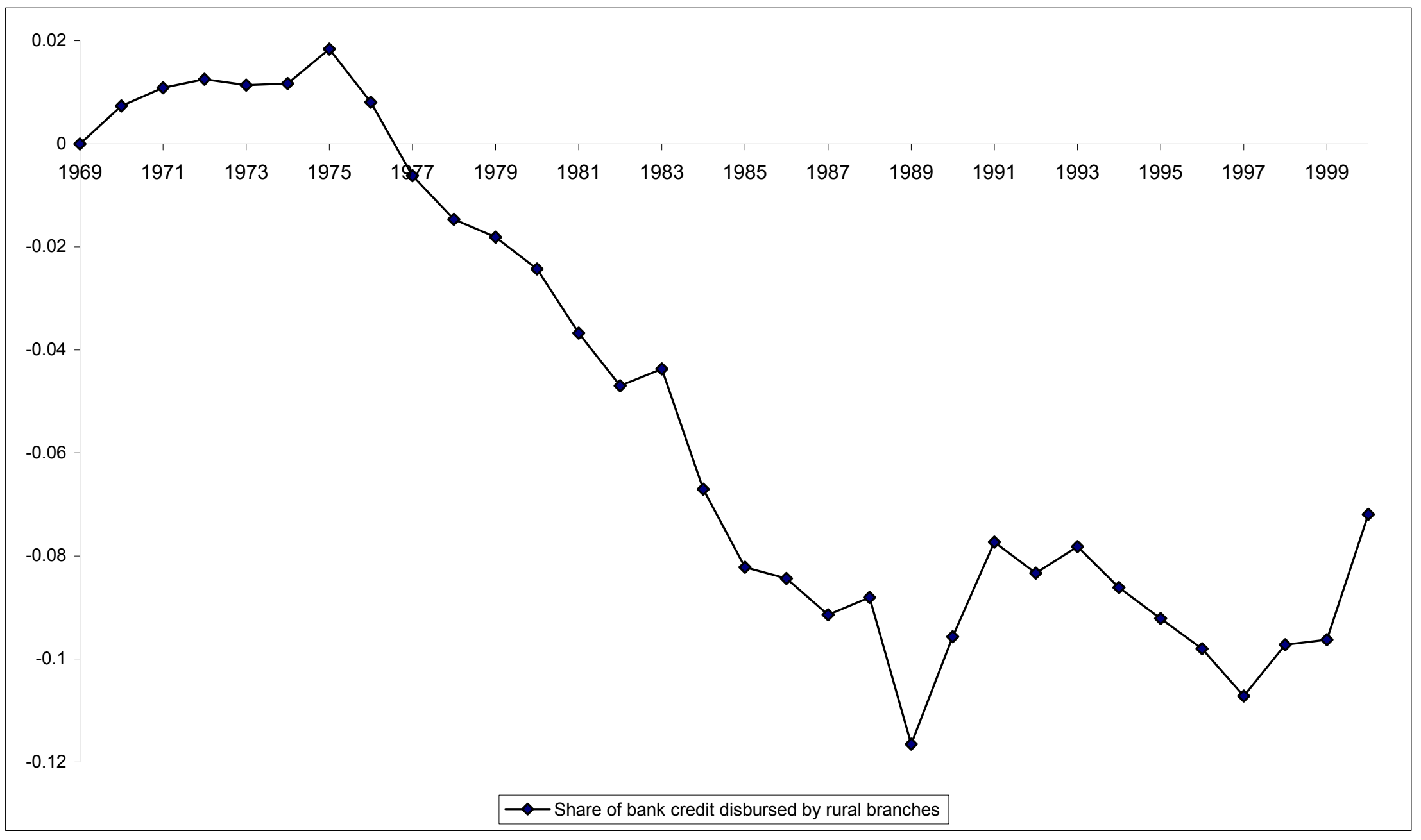

FIGURE 8: INITIAL FINANCIAL DEVELOPMENT AND RURAL CREDIT SHARE

Notes: This figure graphs the set of "Number of banked locations in $1961 \times$ Year" Interaction terms from a regression in which the dependent variable is the share of bank credit disbursed by rural bank branches. The regression includes population, income and location controls, 


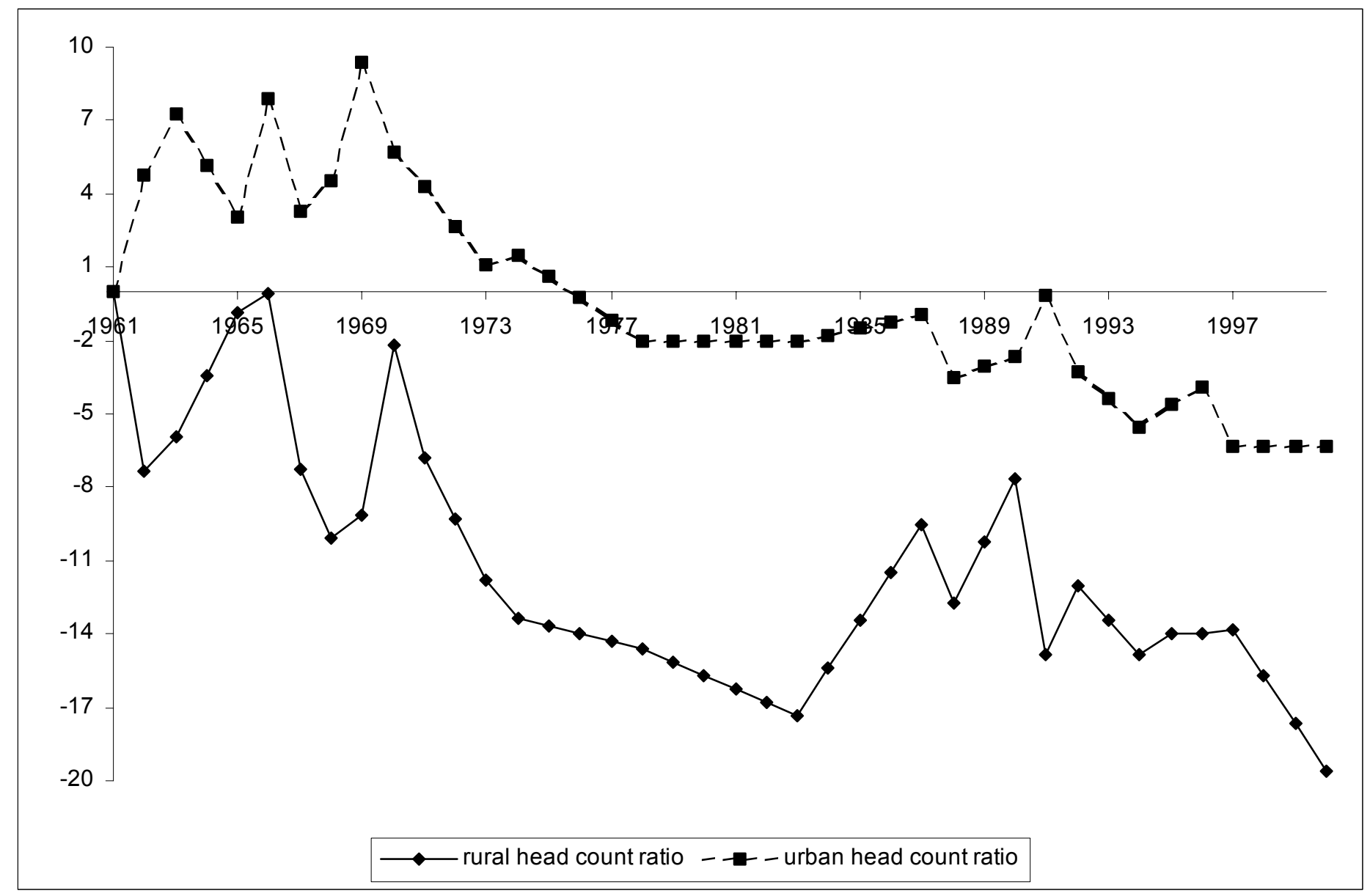

FIGURE 9: INITIAL FINANCIAL DEVELOPMENT AND POVERTY

Notes: This figure graphs the coefficients for two regressions. The series "Rural head count ratio" graphs the set of "Number of banked locations in $1961 \times$ Year" interaction terms from the regression in which the dependent variable is rural head count ratio; the series "Urban head count ratio" graphs the corresponding set of interaction terms from the regression in which the dePendent variable is urban head count ratio. Both regressions include population, income and location controls, 